\title{
ПРОБЛЕМЫ РУДНОЙ ГЕОЛОГИИ И ЧЕЛОВЕЧЕСКИЙ ФАКТОР. ЧАСТЬ 3. МЕТАМОРФИЗМ И МЕЗОТЕРМАЛЬНОЕ РУДООБРАЗОВАНИЕ
}

\author{
Кучеренко Игорь Васильевич, \\ kivr@tpu.ru \\ Национальный исследовательский Томский политехнический университет, \\ Россия, 634050, г. Томск, пр. Ленина, 30.
}

Актуальность. Условия образования известных многочисленных мезотермальных месторождений золота в толщах черных сланцев разного возраста составляют предмет оживленной дискуссии, которая нередко приобретает черты суррогатной и, вероятно, в силу этого бесконечной вследствие исключения конкретным автором или авторским коллективом из учета, анализа, обобщения, обсуждения фактов, важных для решения проблемы, но не вписывающихся в доказательную базу данных разрабатываемых им/ими представлений.

Цель: для получения корректных результатов, необходимых для углубления теории гидротермального рудообразования и разработки, совершенствования комплексов эффективных прогнозно-поисковых критериев оруденения, устранять это негативное проявление человеческого фактора и в процедуре реконструкции процессов рудообразования вернуть дискуссию в нормальное русло посредством включения в научный оборот «удобных» и «неудобных» фактов.

Методы. Выполнен анализ баз данных, предложенных давно и недавно в обоснование метаморфогенно-гидротермальной и других гипотез образования мезотермальных месторождений золота в толщах черных сланцев. Обсуждаются приведенные авторские материалы, в том числе аналитические данные - результаты полного химического силикатного анализа (мокрого) горных пород, атомно-абсорбционного анализа содержания золота, серебра, ртути в горных породах, петрохимических балансовых расчетов межзональной миграции петрогенных элементов в околорудных метасоматических ореолах, математической обработки содержаний в горных породах рудогенных элементов.

Результаты. Сделан вывод о геолого-генетической однородности мезотермальных месторождений золота, образованных в кристаллическом и черносланцевом субстрате. Доказательством этому служат следующие ключевые факты: 1) контроль месторождений глубинными разломами; 2) близкий геологический возраст ранних плутонов, массивов палингенных гранитоидов С многочисленными сопровождающими дайками средне-кислых пород и поздними дайками умеренно-щелочных долеритов, долеритов, лейкодолеритов дорудных, внутрирудных, послерудных генераций, в том числе преобразованными в высокотемпературные биотит-роговообманковые метасоматиты внутрирудными дайками-флюидопроводниками, и руд; 3) аутентичная минералого-петрохимическая зональность околорудных метасоматических ореолов в том и другом субстрате, образованных в условиях калиево-сернисто-углекислотного метасоматизма пропилит-березитового профиля с поступлением в ореолы калия, восстановленной серы, углекислоты, удалением натрия и частично кремния; 4) наследование околорудными метасоматитами петрохимического профиля внутридолеритового метасоматизма и контрастных аномалий фемофильных элементов (P, Mg, Fe, Ti); 5) отвечающие метеоритному стандарту (мантии) изотопные отношения серы сульфидов и углерода карбонатов руд и околорудных метасоматитов. Перечисленные факты исключают участие метаморфизма в рудообразовании. В Ленском районе, как и в других золоторудных районах горно-складчатого обрамления Сибирского кратона, мезотермальные месторождения золота образованы в составе антидромных гранит-диорит-долеритовых флюидно-рудно-магматических комплексов на позднем базитовом этапе их функционирования, а внутрирудные дайки-флюидопроводники преобразованных в высокотемпературные биотит-роговообманковые метасоматиты умеренно щелочных долеритов служат связующим звеном между базитовыми очагами мантии - источниками золотоносных растворов - и месторождениями золота в коре.

Структура статьи. В части 3 статьи приведены разделы: содержание проблем и постановка задачи; минералого-петрохимическая зональность околорудных метасоматических ореолов пропилит-березитового профиля в мезотермальных месторождениях золота, образованных в кристаллическом субстрате и толщах черных сланцев; минералого-петрохимическая зональность околорудного метасоматического ореола золоторудного месторождения Сухой Лог. В части 4 статьи приведены разделы: распределение рудогенных элементов в околорудном пространстве мезотермальных месторождений золота, образованных в кристаллическом субстрате и толщах черных сланцев; обсуждение результатов и выводы; заключение; список литературы.

\section{Ключевые слова:}

Мезотермальные месторождения золота, кристаллический субстрат, черные сланцы, магматизм, метаморфизм, рудообразование, человеческий фактор.

\section{Содержание проблемы и постановка задачи}

История возникновения дважды в ХХ столетии идеи о местных (породных) источниках сосредоточенных в рудах гидротермальных месторождений металлов, составившей в начале века содержание литораль-секреционной гипотезы рудообразования, после забвения в течение нескольких десятилетий возрожденной в шестидесятых-семидесятых годах столетия под названием метаморфогенно-гидротермальной гипотезы, демонстрирует очередной, дополнительный к приведенным ранее $[1,2]$, пример негативного влияния человеческого фактора на процесс познания - разработку, совершенствование теории гидротермального рудообразования и следующего из нее комплекса прогнозно-поисковых критериев оруденения.

В том и в другом случае на начальных этапах обоснования гипотез негативное влияние выразилось во вбросе в научный оборот статистически невыверенных «фактов» о приуроченности гидротермальных месторождений к породам с повышенными (высокими) дорудными, приобретенными в разных геологических процессах, в том числе на этапах седиментации и/или зонального регионально- 
го метаморфизма, содержаниями рассеянных в породах металлов - породам-донорам, из которых, согласно гипотезам, «излишки» - сверхкларковые массы металлов - переотложены при рудообразовании в руды.

Во втором случае негативное влияние человеческого фактора выразилось также в необоснованной должным образом, сохраняющейся до сих пор в работах многих представителей ученого сообщества квалификации вмещающих руды околорудно измененных пород в называемых метаморфогенногидротермальными месторождениях как производных регионального метаморфизма фации зеленых сланцев [3-60]. При этом давно известно, что метаморфические минеральные ассоциации этой фации (хлориты, цоизит, эпидот, альбит, кварц, серицит, карбонаты и др.) образуют также метасоматиты пропилитовой формации, в том числе в обрамлении тыловых зон околорудных метасоматических колонок скарновой, грейзеновой, березитовой, аргиллизитовой формаций [61] и в составе автономной региональной пропилитовой метасоматической формации [62].

В том и другом случае по прошествии непродолжительного времени представление о литологогеохимическом контроле гидротермальных месторождений было дезавуировано - выяснялось, что промышленные гидротермальные месторождения металлов образованы в блоках земной коры, сложенных породами, включая черные сланцы с повышенными и субкларковыми их содержаниями. Утверждались также одинаково низкие содержания золота в черных сланцах золотоносных и незолотоносных районов [4]. Все это означает, во-первых, признание того, что за повышенные ранее принимались околорудные ореольные значения, во-вторых, уровень дорудных концентраций рассеянного во вмещающих породах металла существенно не влияет на образование его промышленных месторождений - требуется дополнительный внешний источник.

Казалось бы, вместе с опровержением не выдержавшего проверку временем представления о литолого-геохимическом контроле оруденения следовало ожидать отказ и от опиравшихся на него гипотез.

Это произошло в первом случае - как эпизод в истории науки осталась литораль-секреционная гипотеза.

Метаморфогенно-гидротермальная гипотеза, сфера приложения которой, в отличие от литораль-секреционной гипотезы, ограничена преимущественно месторождениями золота, урана и вмещающими их толщами черных сланцев, образованными в возрастном диапазоне от позднего архея - раннего протерозоя до современной эпохи, сохраняет популярность в одноэтапном (автономном) и преимущественно в не менее чем двухэтапном (полигенном) вариантах. Последний предполагает «ступенчатое» концентрирование металлов до промышленных их содержаний в ходе независимых геологических процессов [3, 4, 10-12].
Продолжающееся «триумфальное шествие» метаморфогенно-гидротермальной гипотезы со времени ее создания сопровождается расширением перечня геолого-генетических сценариев рудообразования от раннего [3] до современных с вариантами [12-22] - метаморфогенно-гидротермального с концентрированием рассеянного в породах золота метаморфическими или генерированными в гранитных расплавах растворами, гидротермально-осадочного (типа куроко), в том числе с последующими метаморфизмом и/или гранитоидным магматизмом, плутоногенно-гидротермального в генетической связи с магматизмом.

Многообразие и эволюцию представлений об условиях образования одних и тех же золоторудных месторождений можно видеть на примере Байкало-Патомской золоторудной провинции (Ленского золоторудного района) - на родине метаморфогенно-гидротермальной гипотезы, в том числе уникального по запасам золота типового в районе месторождения Сухой Лог и других золоторудных районов.

Один из ранних наиболее популярных сценариев рудообразования в рифейских толщах черных сланцев Ленского района, описавших условия образования открытого в конце шестидесятых годов месторождения Сухой Лог [3], предполагает двухэтапную мобилизацию золота (и, очевидно, сопровождающих металлов) из рассеянного в породах состояния в концентрированное в рудных телах.

Согласно этому сценарию, на раннем этапе в процессе регионального зонального метаморфизма нагревания в обрамлении глубинных разломов под воздействием поступавших глубинных метаморфических (сквозьмагматических) растворов формировались разнофациальные колонки в составе зон, отвечающих:

- амфиболитовой фации (со слюдяными, редкометальными, керамическими пегматитами);

- эпидот-амфиболитовой фации (с безрудными кварцевыми жилами, иногда с редкометальным, редкоземельным оруденением);

- зеленосланцевой фации, биотит-хлоритовой субфации (со слабо золотоносными кварцевыми жилами и пирит-пирротиновой минерализацией в породах);

- зеленосланцевой фации, хлорит-серицитовой субфации (с основной массой наиболее богатых золотом кварцевых жил, с альбитом и $\mathrm{Mg}-\mathrm{Fe}$ карбонатами, золото-сульфидной преимущественно пиритовой минерализацией);

- цеолитовой фации (с полиметаллическим оруденением).

Согласно заключению В.А. Буряка, автора приведенного раннего варианта гипотезы, зависимость золотой минерализации от степени метаморфизма пород выражается в миграции - диффузии в застойных поровых растворах золота (и сопровождающих металлов) - из области интенсивного метаморфизма в периферийные зоны более слабого, 
сопровождаемой обеднением пород металлами в первой и равномерным обогащением ими пород во второй. Для образования месторождений требуется повторная (на втором этапе) мобилизация металлов из обогащенных ими на первом этапе пород, которая обеспечивается фильтрующимися по разломам, генерированными в очагах гранитной магмы растворами с последующим концентрированием и отложением металлов в локальных структурах.

Более поздние сценарии образования месторождения Сухой Лог включают один [8, 9], два [10] и четыре $[11,12]$ этапа.

По одноэтапному сценарию рассеянное в породах золото переотложено в руды в процессе тектоно-магматической активизации.

По двухэтапному сценарию прожилково-вкрапленные метасоматические рудные залежи образованы на раннем этапе в процессе палеозойской тектоно-магматической активизации посредством гидротермально-метасоматического преобразования черных сланцев рудовмещающей позднерифейской хомолхинской свиты $447 \pm 6$ млн л. назад, 30лотоносные кварцевые жилы - на позднем этапе $321 \pm 14$ млн л. назад.

Четырехэтапный сценарий образования месторождения Сухой Лог, с незначительными изменениями подтвержденный в [12], предполагает первоначальное накопление металлов в осадках на позднерифейском этапе седиментации, обусловившее геохимическую специализацию вмещающих руды пород. На следующих этапах катагенеза и через 100-150 млн л. на метаморфогенно-метасоматическом происходит перераспределение металлов. Прожилково-вкрапленное оруденение окончательно оформляется на завершающем среднепозднепалеозойском этапе (350-312 20 млн л.) в условиях зонального метаморфизма и палингенноанатектического гранитообразования.

Все сценарии не подкреплены аналитическими данными, раскрывающими геологическую историю золота и сопровождающих его металлов, как и корректными доказательствами поэтапного концентрирования их в ходе и результате соответствующих геологических процессов. Поэтому сценарии включают версии, достоверность которых неизвестна.

По одному из современных сценариев [13] метаморфогенно-гидротермальное рудообразование в Ленском районе Байкало-Патомской металлогенической провинции началось с формирования в зонах складчато-разрывных дислокаций среди черных сланцев, подвергшихся региональному метаморфизму гидратации фации зеленых сланцев, золотоносной минерализации в составе $\mathrm{Mg}-\mathrm{Fe}$ карбонатов с насыщением ими пород до 50 об. \%. Золоторудные месторождения образованы только в пределах таких структур «бурошпатизации» в «30не хлорита» ареала зеленосланцевого метаморфизма. При этом смежные зоны пирротина и биотита региональной метаморфической колонны, а также зона пренит-пумпеллиитовой фации остаются безрудными. Все перечисленные зоны «близко одновременны», но с незначительным запаздыванием зон хлорита и пренит-пумпеллиита относительно зон пирротина и биотита. Все это автор сценария А.И. Иванов квалифицирует как свидетельство образования золотоносных зон «бурошпатизации» при складкообразовании в диапазоне Р-Т-условий, соответствующих «зоне хлорита».

На следующем этапе регионального метаморфизма нагревания (гранито-гнейсового куполообразования) ранее образованные в рудоконтролирующих структурах сидерит и анкерит («бурые шпаты») замещены кварцем, биотитом и другими минералами с высвобождением и укрупнением тонкодисперсного в карбонатах золота. Золоторудная минерализация образована в послеметаморфических (диафторических) анкерит-кварцевых жилах в низкотемпературных условиях. Синметаморфические (ранние на этом этапе) кианит-кварцевые жилы безрудны.

На завершающем этапе сингранитного (конкудеро-мамаканский комплекс) метаморфизма окончательно формировались золоторудные месторождения (сульфидно-кварцевые жильно-прожилковые системы) в ранее образованных золотоносных структурах рассланцевания и «бурошпатизации» в P-Т-условиях «зоны хлорита» в процессах гидротермально-метаморфического рудообразования с участием как метаморфических, так и сингранитных флюидов (как различаются? - И.К.). Предполагается дополнительный привнос золота (аргументы? - И.К.). В условиях интенсивного проявления диафтореза (почему не пропилитизации? - И.К.) образованы вмещающие золото-кварц-сульфидные прожилки, анкерит-кварцевые жилы с видимым золотом, существенно мусковитовые и кварц-хлорит-анкерит-мусковитовые метасоматиты.

Согласно другому сценарию, группа месторождений «сухоложского» типа (Сухой Лог, Вернинское, Высочайшее) отнесена к гидротермально (эксгаляционно)-осадочным, подвергшимся частичной регенерации в условиях метаморфизма зеленосланцевой фации [14-15]. Залежи слоистых, линзовидно-пластовых, послойно-вкрапленных золото-сульфидных руд отложены в конседиментационных впадинах в обрамлении рудоподводящих (раствороподводящих - И.К.) разломов с последующей регенерацией на коллизионном этапе. Подчеркивается пересечение зонами первичного (курсив наш - И.К.) обогащения осадков серой и золотом литологических границ, вследствие чего эти зоны при оконтуривании по бортовому содержанию будут выделены как секущие (курсив наш И.К.) рудные тела [14]. Для месторождений, согласно автору сценария, характерно отсутствие околорудных геохимических (кроме мышьяка), метасоматических ореолов, монометальность (? И.К.), пиритовый состав руд (? - И.К.). Предполагается поступление золота из магматических, в том числе мантийных, источников. Подобные ме- 
сторождения известны в Центрально-Колымском регионе (Хатыннах-Олботское [16]), Енисейском кряже (Олимпиада), Кызыл-Кумах (Амантайтау).

При разных сценариях образования мезотермальных месторождений золота в Урик-Китойской золоторудной зоне Восточного Саяна некоторые объекты (Зун-Холбинское, Барун-Холбинское, Зун-Оспинское, Пионерское месторождения) объединяются в метаморфогенно-гидротермальную генетическую группу [17]. В данном случае природой задолжен, как считает автор сценария, механизм мобилизации золота и сопровождающих его металлов из обладающих повышенными их содержаниями пород офиолитовой ассоциации или образованной на этапе седиментации сульфидной минерализации метаморфогенными растворами. Отложение рудного вещества происходило на геохимических и термодинамических барьерах в зонах тектонических деформаций - сдвига, надвига, осевых частей зон меланжа вследствие снижения температуры и давления в рудообразующих систеmax.

В Тыйско-Олокитском метаморфическом поясе Северного Прибайкалья в процессе дислокационного метаморфизма или дислокационно-гидротермального метасоматизма в зонах диафтореза (так у авторов - И.К.) среди биотит-хлоритовых и других сланцев биотит-хлоритовой субфации зеленосланцевой фации ранне- и позднепротерозойских комплексов образованы метаморфогенные кварцевые, кварцево-карбонатные, кварцево-сульфидные жилы, прожилки, линзовидные тела в зонах рассланцевания, катаклаза, милонитизации мощностью до 300 м и протяженностью до 15 км [18]. Подчеркивается прямая зависимость золотоносности диафторитов от интенсивности метасоматических преобразований пород в зонах диафтореза (так у авторов - И.К.) - чем интенсивнее проявлен метасоматизм, тем выше золотоносность диафторитов. По мнению авторов сценария, источниками $\mathrm{Au}$, $\mathrm{Ag}, \mathrm{As}, \mathrm{Cu}, \mathrm{Pb}, \mathrm{Zn}, \mathrm{S}$ служили вмещающие породы.

В результате детального изучения вмещающих черных сланцев и руд золотых месторождений Артемовского золоторудного узла Ленского района составов минералов, текстур и структур руд, кристаллохимии породообразующих и акцессорных минералов, преобразований углеродистого вещества, изотопных составов кислорода кварца, свинца галенита, составов элементов-примесей в минералах пород и руд - выделены минеральные ассоциации: слабо золотоносная (до 2,9 г/т золота в рассеянном в породах пирите - первая сингенетическая и диагенетическая (седиментогенная), еще слабее на порядок золотоносная (в среднем 0,22 и 0,36 г/т золота в рассеянном в породах пирите вторая катагенетическая и метаморфогенная, поздняя золотоносная (Au в свободной форме и в сростках с сульфидами) в кварцевых и кварц-карбонатных жилах с сульфидами цветных металлов [19]. Вмещающие породы метаморфизованы в условиях серицит-хлоритовой субфации зеленосланцевой фации при образовании месторождений в диапазоне температур $320-380{ }^{\circ} \mathrm{C}$ без участия гидротермальных растворов из внешнего источника. Поскольку внешние источники металлов, в том числе золота, исключены, а процессы диагенеза, катагенеза и метаморфизма до сих пор считаются изохимическими, остается предположить версию автора сценария о накоплении металлов в породах только на этапе седиментации.

Согласно одной из версий метаморфогенного сценария образования золоторудных месторождений Яно-Колымского и Монголо-Охотского орогенных поясов, рудоносность рудоконтролирующих надвиговых структур - одношовных и многошовных надвигов, зон тектонического и автокластического меланжа (милонитов, бластомилонитов, катаклазитов, тектонобрекчий, раскристаллизованных псевдотахилитов) - определяется геохимической специализацией на золото и сопровождающие его в рудах металлы различных по происхождению и составам петротипов исходных горных пород, преобразованных в результате динамометаморфических (тектоно-метаморфических) процессов в условиях деформаций сжатия [20]. Одновременно с этим подчеркивается - продуктивность каждого типа рудоконтролирующих структур определяется степенью (интенсивностью) динамометаморфических преобразований исходных горных пород.

Метаморфогенно-гидротермальное образование мезотермальных месторождений золота посредством переотложения сверхкларковых масс металла (металлов) из различных «специализированных» на золото пород, в основном черных сланцев разного возраста, или из низкоконцентрированной золотоносной минерализации разного происхождения гидротермальными метаморфогенными или генерированными преимущественно в обводненных гранитных расплавах, или так называемыми «глубинными» растворами, по-прежнему обосновывается, описывается, декларируется без должного обоснования в многочисленных публикациях недавнего и последнего времени [21-60]. Вместе с тем первоначальным сценариям противопоставляются альтернативные - акцент постепенно смещается от сценариев, предполагающих (описывающих) мобилизацию золота с сопровождающими металлами из рассеянного в породах состояния в концентрированное в рудах, $\mathrm{\kappa}$ сценариям, описывающим первоначальное (на раннем этапе) накопление золотоносной минерализации посредством механизмов гидротермально-осадочного сингенетического (типа куроко) или гидротермально-метасоматического в разломных структуpax эпигенетического минералообразования с последующими преобразованиями в условиях функционирования метаморфогенных и/или магматогенных растворов.

Приведенные материалы демонстрируют многообразие представлений об условиях образования в черносланцевых толщах разных месторождений, 
которое сочетается с многообразием представлений об условиях образования одного месторождения, в данном случае Сухого Лога, в течение 50 лет изученного «вдоль и поперек», но для которого предложено разными авторами и авторскими коллективами не менее упомянутых выше четырех версий его образования, исключающих одна другую. В первом случае многообразие может быть объяснено (обусловлено) тем, что природа создала разные месторождения по действительно разным сценариям. Во втором случае многообразия не должно быть - сценарии, кроме одного или все, ложные. Следствие последнего - происхождение (генезис) этого уникального месторождения остается terra incognita. Доказательство тому заключено, помимо прочего, в использовании авторами последних сценариев в выводах неконкретных мало о чем говорящих терминов без раскрытия их содержания: эндогенные флюиды, дайковый магматизм, эндогенные источники серы и золота, рудогенерирующий очаг, глубинные источники сосредоточенных в рудах металлов, комплексы малых интрузий и даек пестрого состава и т. д. Очевидная причина использования таких терминов - дефицит (отсутствие) у авторов сценариев конкретной информации, необходимой и достаточной для корректного доказательства и описания содержания рудообразующих процессов, в итоге - для углубления, совершенствования теории гидротермального рудообразования и следующего из нее комплекса эффективных прогнозно-поисковых критериев оруденения.

Приведенные результаты работы предшественников последнего времени и современников демонстрируют одно из негативных проявлений в исследовании данной (и не только) проблемы - человеческого фактора, формирующего препятствия на пути к достижению обозначенной ключевой цели, - игнорирование (исключение из обсуждения) многими участниками эпопеи опубликованных в доступных изданиях фактов, которые не вписываются в доказательную базу разрабатываемых ими представлений. Противоречащие представлениям факты «не замечаются». В течение многих лет изучения обсуждаемой проблемы дискуссия продолжается на параллельных (не пересекающихся) курсах с соблюдением массами редко и несущественно нарушаемого, вероятно, продиктованного уважением чувств коллег принципа - мы не трогаем вас, вы не трогайте нас. Затруднительно признать корректными результаты, полученные в «тепличных» условиях, без содержательного обсуждения «неудобных» фактов в процессе реальной дискуссии - борьбы идей, фактов, аргументов. Пока создается впечатление - исключение из обсуждения «неудобных» фактов есть свидетельство озабоченности причастных к решению проблемы авторов публикаций - апологетов геолого-генетических сценариев образования мезотермальных месторождений золота, составляющих основу метаморфогенно-гидротермальной гипотезы, чем угод- но, но не поиском истины. По этой, в частности, причине дискуссия обещает быть бесконечной. Невозможно представить подобную свободу нравов в области, скажем, медицины, фармакологии, в которых принимаемые на основе исследований решения влияют на жизнь людей, более того, от которых зависит их жизнь.

Включением в научный оборот - обсуждение проблемы метаморфогенно-гидротермального образования мезотермальных месторождений золота накопленных до сего времени достоверных, исключающих неоднозначную интерпретацию, опубликованных давно и недавно, но замалчиваемых («не замечаемых»), очевидно, по причине невозможности объяснить с позиции метаморфогенной гипотезы необъяснимое, фактов достигается возможность решать проблему в комфортных условиях нормальной дискуссии - эффективного условия в недалекой перспективе решить проблему. С этой целью в статье приведены и обсуждаются в том числе «не замечаемые» авторами разных версий метаморфогенной гипотезы факты. К числу последних относятся:

- факты, раскрывающие в сравнительном аспекте минералого-петрохимическую и геохимическую зональность околорудных (рудовмещающих) метасоматических и геохимических ореолов в мезотермальных месторождениях золота, образованных в кристаллическом и черносланцевом субстрате;

- факты, раскрывающие причинно-следственные связи мезотермальных месторождений золота той и другой совокупности с магматизмом; - факты, дополняющие (подтверждающие) аргументацию следующей из обсуждения перечисленных и других известных фактов генетической концепции рудообразования, альтернативной метаморфогенно-гидротермальной.

\section{Минералого-петрохимическая зональность околорудных метасоматических ореолов пропилит-березитового профиля в мезотермальных месторождениях золота, образованных в кристаллическом субстрате и толщах черных сланцев}

В исследовании геологических процессов, создающих в толщах черных сланцев мезотермальные месторождения золота, урана, цветных металлов, к числу актуальных генетических проблем относится, в частности, трудно решаемая и до сих пор не решенная проблема реконструкции условий околорудных изменений вмещающих руды пород с образованными в них эпигенетическими, как считается - этапов рудообразования, минеральными ассоциациями в составе, как отмечалось, кварца, серицита, хлоритов, минералов эпидотовой группы, альбита, карбонатов и других минералов в разных видовых и количественных соотношениях. Трудность заключается в том, что эти минеральные ассоциации конвергентны и для корректной диагностики принадлежности их к производным 
метаморфизма гидратации фации зеленых сланцев или к магматогенной пропилитовой метасоматической формации требуется выполнение некоторых операций, которыми авторы публикаций, судя по содержанию последних, пренебрегают и принимают решения, исходя из своих предпочтений, но без привлечения дополнительных данных в обоснование принятых решений. Между тем природа оставила указания, которые обеспечивают корректное решение этой ключевой проблемы.

Структура универсальных типовых околоразломных околорудных зональных метасоматических ореолов, вмещающих в мезотермальных месторождениях рудоносные кварцевые жилы и/или залежи жильно-прожилково-вкрапленных руд, представляет собой сочетание периферийных фронтальной, хлоритовой (эпидотовой, эпидотхлоритовой) минералого-петрохимических $30 \mathrm{H}$ пропилитовой формации и внутренних альбитовой и тыловой березитовой (лиственитовой) минералого-петрохимических зон березитовой формации (рисунок, табл. 1) [1].

Универсальный статус ореолов-колонок определяется сходными минеральными составами метасоматитов и минералого-петрохимическими изменениями разных исходных пород, мало влияющих на производные метасоматических процессов, в основном на фиксацию примесей в метасоматических минералах, на образование разновидностей последних, на количественные соотношения минеральных видов и разновидностей. В разных по минеральному, химическому составам и происхождению породах, включая толщи черных сланцев, формируется единый порядок минералого-петрохимической зональности с наиболее мощной, в проницаемых породах до многих сотен - первых тысяч метров, фронтальной зоной при последовательно уменьшающихся мощностях промежуточных зон вплоть до наименее мощной тыловой березитовой (лиственитовой) зоны полного преобразования исходных пород мощностью до сантиметров - десятков сантиметров. Напротив, в рудовмещающих массивных (слабо проницаемых) породах, например в гранитах раннепротерозойского кодарского комплекса в Верхне-Сакуканском месторождении золота Северного Забайкалья, мощность околожильного метасоматического ореола с его фронтальной зоной достигает всего $10 \mathrm{~m}$.

В толщах черных сланцев не очень редкое явление - отсутствие тыловой зоны или повторяющееся чередование минералого-петрохимических зон в разных сочетаниях. При отсутствии в разрезе ореолов тыловой и смежной альбитовой зон обычно осветленных березитов, обусловленном сильно восстановительным режимом локальной черносланцевой среды (например, на Западном участке месторождения Сухой Лог), золоторудные кварцевые жилы и залежи жильно-прожилково-вкрапленных руд образованы в хлоритовой зоне рудовмещающей пропилитовой формации. В этом случае возникает желание или предлог квалифициро- вать околорудные изменения черных сланцев как результат регионального метаморфизма гидратации фации зеленых сланцев. Подобные ситуация и квалификация, вероятно, послужили одним из импульсов к возникновению метаморфогенно-гидротермальной гипотезы рудообразования.

Фронтальная зона типовой рудовмещающей метасоматической колонки, сложенная исходными породами, дифференцирована по объему минеральных новообразований на подзоны слабого (до 10 об. \%), умеренного (10...20 об. \%), интенсивного $(20 . . .30$ об. \% ) изменения с тем, чтобы единообразно использовать наименее измененные породы при отсутствии (недоступности) неизмененных в качестве исходных при петрохимических пересчетах, в частности, для оценки межзональной миграции компонентов. Внутренняя граница зоны совпадает с рубежами полного растворения цветных минералов исходных пород как наиболее подверженных свойственному процессу кислотному выщелачиванию - оливина, пироксенов, обыкновенной роговой обманки, биотита, а также наиболее высокотемпературных этапа метасоматизма актинолита и тремолита в сравнении с полевыми шпатами и нерастворимым в кислотных средах кварцем. Общий объем эпигенетических поименованных ниже минералов в разных сочетаниях в зоне, как и в других зонах, возрастает в направлении к возмущающему объекту - трещинному горячему раствору, следовательно, - к внутренней границе зоны.

В смежной более тыловой хлоритовой (эпидотовой, эпидот-хлоритовой) зоне частично сохраняются реликтовые полевые шпаты, кероген, полностью кварц исходных пород. Ассоциации эпигенетических минералов включают кварц, серицит, магнетит, пирит, рутил, лейкоксен, апатит, кальцит, доломит, альбит, цоизит, клиноцоизит, эпидот, хлориты, золото, серебро в различных видовых и количественных соотношениях. На внутренней границе зоны полностью растворены хлориты и/или минералы эпидотовой группы.

В альбитовой зоне ассоциация новообразованных минералов дополнена анкеритом, сидеритом, апатитом, сульфидами, на ее внутренней границе полностью растворены реликтовые полевые шпаты, альбит, окислен кероген (рисунок).

Тыловая зона сложена в полном объеме эпигенетическими кварцем (в сочетании с реликтовым кварцем исходных пород), серицитом, магнетитом, пиритом (сульфидами), рутилом, лейкоксеном, кальцитом, доломитом, анкеритом, сидеритом, брейнеритом, с примесью апатита, золота, серебра. Обычны разные сочетания перечисленных карбонатов.

Типовые черты межзональной миграции петрогенных компонентов при околорудном метасоматизме независимо от составов и происхождения вмещающих оруденение исходных (включая черные сланцы) горных пород (табл. 1) выражаются в удалении преимущественно из тыловых зон фор- 


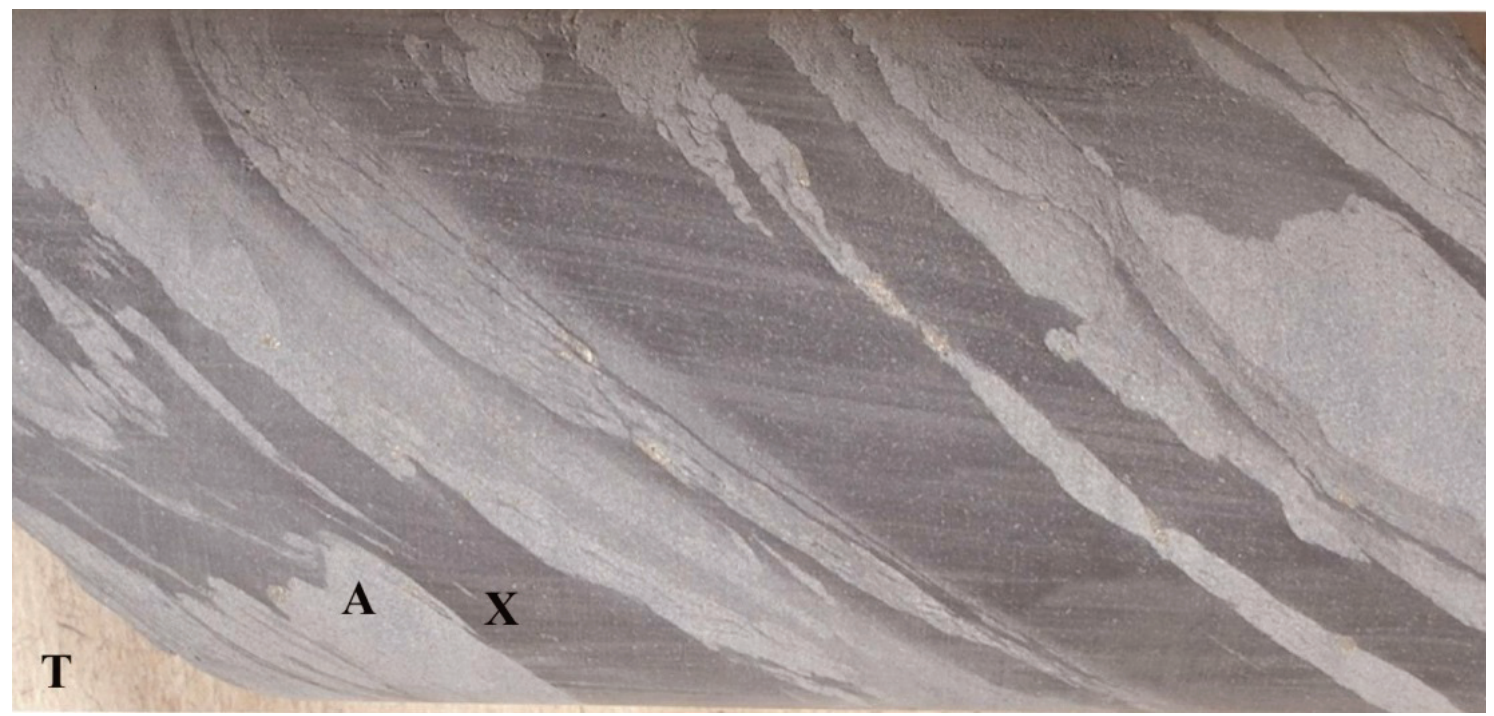

Рисунок. Тыловая (березитовая) зона (T) в контакте с альбитовой зоной (A), хлоритовая зона (Х) рудовмещающего метасоматического ореола Вернинского месторожления. Керн (натуральная величина)

Figure. Rear (beresite) zone ( $T$ ) in contact with albitic zone (A), chloritic zone $(X)$ of ore containing metasomatic halo of Verninskoe deposit. Core (natural size)

мирующихся метасоматических колонок кремния (до 50 мас. \% от исходного содержания), натрия (до 90 мас. \%), поступлении преимущественно в тыловые зоны и фиксация в них калия в сериците (до 600 мас. \%), углекислоты в карбонатах (до 7900 мас. \% в расчете на $\mathrm{CO}_{2}$ ), восстановленной серы в сульфидах (до 42800 мас. \%). В ближнем (до 1,5...2,0 км) обрамлении глубинных и оперяющих их разломов из поступавших извне металлоносных растворов в поровые растворы боковых пород вплоть до хлоритовой, в некоторых колонках до фронтальной зон включительно, диффундируют [1] химические элементы фемофильной ассоциации $\mathrm{Ca}, \mathrm{Mg}, \mathrm{Fe}, \mathrm{Mn}, \mathrm{Ti}, \mathrm{P}$, содержание которых в тыловых зонах увеличивается на первые-многие сотни мас. \% сравнительно с содержаниями их в исходных породах. $\mathrm{Ca}, \mathrm{Mg}, \mathrm{Fe}, \mathrm{Mn}$ фиксируются в карбонатах, $\mathrm{Ti}$ - в рутиле, лейкоксене, $\mathrm{P}$ - в апатите.

Упомянутые выше указания природы, доказывающие принадлежность эпигенетических этапов рудообразования, минеральных ассоциаций околорудно гидротермально измененного вмещающего мезотермальное оруденение кристаллического и черносланцевого субстрата, в отличие от ареалов регионального метаморфизма гидратации фации зеленых сланцев, к сочетающимся в объеме одной зональной метасоматической колонки не свойственной региональному метаморфизму березитовой метасоматической формации в ее тылу и пропилитовой в обрамлении, заключаются в следующем.

- Межзональная миграция компонентов при околорудном метасоматизме в околоразломном варианте происходит в объеме всей метасоматической колонки.

- Как следует из результатов петрохимических пересчетов (табл. 1), термо-динамические и фи- зико-химические режимы метасоматического процесса березитового петрохимического профиля обеспечивают подвижность (способность к миграции - диффузии с различной скоростью в соответствии со свойствами всех, включая фемофильные, согласно теории метасоматической зональности Д.С. Коржинского [1], «инертные при всех условиях») компонентов, кроме глинозема, обладающего ограниченной подвижностью в условиях кислотного процесса.

- Большинство компонентов мигрирует - диффундирует - в пределах хлоритовой, альбитовой, тыловой березитовой минералого-петрохимических зон. Наиболее подвижные калий, сеpa, углекислота в ряде колонок достигают фронтальной зоны (колонки I, III, IV, VII, VIII, XV, в черных сланцах колонки XVI, XVIII). В некоторых колонках (апочерносланцевой XVIII) фронтальной зоны достигают также фемофильные компоненты.

- В системах околоразломного метасоматизма «трещинный раствор - поровый раствор-горная порода» в условиях встречной диффузии компонентов массы диффундирующих из трещинных растворов в поровые компонентов максимально зафиксированы в составах минералов тыловых зон и последовательно уменьшаются от одной минералого-петрохимической зоны к другой в направлении к фронтальной зоне. Напротив, массы диффундирующих из поровых растворов в трещинные компонентов $(\mathrm{Si}, \mathrm{Na})$ увеличиваются в направлении к тыловой зоне, достигая в последней до 50 мас. \% ( $\mathrm{Si})$ и до 90 мас. \% (Na) от их масс в исходных породах. Приведенные материалы доказывают одновременное с березитами тыловых зон образование сложенных эпигенетическими «зеленосланцевыми» 
Таблица 1. Коэффициенты распределения (КР) (выноса $<1$, привноса $>1$ ) петрогенных элементов в минералого-петрохимических зонах околорудных метасоматических ореолов гидротермальных золоторудных месторождений юго-восточного складчатого обрамления Сибирского кратона

Table 1. Coefficients of distribution (CD) (carry out $<1$, addition $>1$ ) of petrogenic elements in mineral zones of near ore metasomatic haloes of hydrothermal gold deposits in South-East folded frame of Siberian craton

\begin{tabular}{|c|c|c|c|c|c|c|c|c|c|c|c|c|c|c|c|c|}
\hline \multirow{2}{*}{$\begin{array}{l}\text { Минералого-петрохимические зоны и подзоны (число проб) } \\
\text { Mineral-Petrochemic zones and subzones (number of samples) }\end{array}$} & \multicolumn{15}{|c|}{ Химические элементы/Chemical elements } & \multirow{2}{*}{$\Delta$} \\
\hline & $\mathrm{Si}$ & $\mathrm{Al}$ & $\mathrm{K}$ & $\mathrm{Na}$ & S* & $\mathrm{C}_{\text {кб. }}$ & $\mathrm{Ca}$ & $\mathrm{Mg}$ & $\mathrm{Fe}^{2+}$ & $\mathrm{Fe}^{3+}$ & $\mathrm{Ti}$ & $\mathrm{Mn}$ & $P$ & $\mathrm{H}^{+}$ & 0 & \\
\hline \multicolumn{17}{|c|}{$\begin{array}{c}\text { Кристаллический (несланщевый) субсстрат/Crystal (non-shale) substratum } \\
\text { Ирокиндинское месторождение/Irokindinskoe deposit } \\
\text { I.Альмандин-диопсид-двуполевошпатовые парагнейсы (AR, } 9 \text { проб)/I.Almandine-diopside-two-feldspathic par }\end{array}$} \\
\hline$\Phi \mathrm{У}(23)$ & 1,1 & 1,1 & 1,7 & 1,3 & 3,8 & 0,8 & 0,7 & 1,0 & 1,2 & 0,9 & 1,1 & 1,0 & 1,1 & 1,3 & 1,0 & 8,0 \\
\hline ФИ (14) & 1,1 & 1,1 & \begin{tabular}{|l|}
1,7 \\
\end{tabular} & \begin{tabular}{|l|}
1,2 \\
\end{tabular} & 2,1 & \begin{tabular}{|l|}
0,7 \\
\end{tabular} & \begin{tabular}{|l|}
0,6 \\
\end{tabular} & \begin{tabular}{|l|}
1,0 \\
\end{tabular} & $\mid 1,1$ & 1,0 & 1,1 & \begin{tabular}{|l|}
0,8 \\
\end{tabular} & $\mid 1,4$ & 2,3 & 1,0 & 11,2 \\
\hline $\mathrm{X}(11)$ & 1,0 & 1,0 & \begin{tabular}{|l|}
2,3 \\
\end{tabular} & \begin{tabular}{|l|}
1,4 \\
\end{tabular} & 1,5 & 1,6 & 0,4 & 1,5 & 1,2 & \begin{tabular}{|l|}
0,6 \\
\end{tabular} & 1,1 & \begin{tabular}{|l|}
0,6 \\
\end{tabular} & \begin{tabular}{|l|}
0,9 \\
\end{tabular} & 3,7 & 1,0 & 13,9 \\
\hline $\mathrm{A}(10)$ & 0,9 & 1,1 & \begin{tabular}{|l|}
3,4 \\
\end{tabular} & \begin{tabular}{|l|}
1,3 \\
\end{tabular} & \begin{tabular}{|l|}
8,1 \\
\end{tabular} & \begin{tabular}{|l|}
2,0 \\
\end{tabular} & 0,4 & \begin{tabular}{|l|}
0,9 \\
\end{tabular} & $\mid 1,4$ & \begin{tabular}{|l|}
0,6 \\
\end{tabular} & 1,5 & \begin{tabular}{|l|}
0,7 \\
\end{tabular} & \begin{tabular}{|l|}
0,9 \\
\end{tabular} & 3,3 & 1,0 & 17,2 \\
\hline $\mathrm{T}(26)$ & 0,9 & 1,1 & 4,1 & 0,2 & 14,9 & 2,4 & 0,5 & 1,4 & 1,5 & $\mid 0,7$ & 1,6 & 0,8 & 1,1 & 3,9 & 1,0 & 20,2 \\
\hline \multicolumn{17}{|c|}{ II.Альмандин-двуслюдяные парагнейсы (AR, 14 проб)/II.Almandine-two-mica paragneisses (AR, 14 samples) } \\
\hline$\Phi У(9)$ & 0,9 & 1,1 & 1,1 & 0,9 & 1,1 & 1,2 & 1,3 & 1,5 & 1,1 & 1,1 & 1,1 & 1,5 & 1,4 & 1,6 & 1,0 & 5,6 \\
\hline ФИ (11) & 1,0 & 1,0 & 1,0 & 0,9 & 0,9 & 1,4 & 0,7 & 1,2 & 1,0 & \begin{tabular}{|l|}
1,4 \\
\end{tabular} & 1,2 & 1,1 & \begin{tabular}{|l|}
0,8 \\
\end{tabular} & 2,5 & 1,0 & 4,0 \\
\hline $\mathrm{X}(7)$ & 1,0 & 1,0 & 1,0 & \begin{tabular}{|l|}
0,7 \\
\end{tabular} & \begin{tabular}{|l|}
2,2 \\
\end{tabular} & 4,0 & \begin{tabular}{|l|}
0,9 \\
\end{tabular} & 1,2 & 1,0 & \begin{tabular}{|l|}
1,5 \\
\end{tabular} & \begin{tabular}{l|l}
1,2 \\
\end{tabular} & 1,1 & \begin{tabular}{|l|}
0,9 \\
\end{tabular} & 2,3 & 1,0 & 5,3 \\
\hline $\mathrm{A}(6)$ & 0,8 & 1,0 & 1,4 & 0,5 & \begin{tabular}{|l|l|}
4,1 \\
\end{tabular} & \begin{tabular}{|l|}
19 \\
\end{tabular} & 1,2 & 1,4 & 1,1 & \begin{tabular}{|l|}
0,9 \\
\end{tabular} & \begin{tabular}{l|l|}
1,3 \\
\end{tabular} & 1,1 & 1,0 & 2,3 & 1,0 & 12,6 \\
\hline $\mathrm{T}(7)$ & 0,9 & 1,0 & $\mid 1,7$ & 0,1 & 37 & 16 & 1,0 & 1,1 & $\mid 0,7$ & 1,6 & 1,0 & 1,6 & $\mid 0,9$ & 1,9 & 1,0 & 13,8 \\
\hline \multicolumn{17}{|c|}{ III. Кальиифиры (AR, 6 проб)/III. Calciphyres (AR, 6 samples) } \\
\hline$\Phi У(13)$ & \begin{tabular}{|l|}
1,0 \\
\end{tabular} & 1,0 & \begin{tabular}{|l|}
0,9 \\
\end{tabular} & \begin{tabular}{|l|}
1,2 \\
\end{tabular} & 1,5 & \begin{tabular}{|l|}
1,0 \\
\end{tabular} & \begin{tabular}{|l|}
1,0 \\
\end{tabular} & 1,0 & \begin{tabular}{|l|}
1,2 \\
\end{tabular} & 0,7 & 1,0 & 1,8 & 1,1 & 0,9 & 1,0 & 2,9 \\
\hline ФИ (7) & 1,0 & 1,0 & 1,3 & 1,0 & 5,5 & \begin{tabular}{l|}
1,0 \\
\end{tabular} & 0,9 & 1,0 & \begin{tabular}{|l|}
0,9 \\
\end{tabular} & \begin{tabular}{|l|}
0,6 \\
\end{tabular} & \begin{tabular}{l|l}
1,1 \\
\end{tabular} & 1,3 & 1,2 & 3,0 & 1,0 & 4,8 \\
\hline $\mathrm{X}(6)$ & 0,7 & 0,8 & 1,0 & 0,6 & 3,5 & 1,4 & 1,0 & 0,9 & \begin{tabular}{|l|}
0,9 \\
\end{tabular} & \begin{tabular}{|l|}
0,7 \\
\end{tabular} & \begin{tabular}{l|}
1,0 \\
\end{tabular} & 0,8 & 1,1 & 1,6 & 1,0 & 9,5 \\
\hline $\mathrm{A}(8)$ & 1,0 & 1,1 & 1,8 & 1,2 & 4,4 & \begin{tabular}{l|}
1,1 \\
\end{tabular} & 0,7 & 1,3 & 1,3 & \begin{tabular}{|l|}
0,5 \\
\end{tabular} & \begin{tabular}{l|}
1,3 \\
\end{tabular} & 1,4 & 1,3 & 2,3 & 1,0 & 13,7 \\
\hline $\mathrm{T}(18)$ & 1,0 & 1,3 & 3,0 & 0,3 & 22 & 1,0 & 0,5 & 1,8 & 1,8 & 0,5 & 1,8 & 1,8 & 1,9 & 4,1 & 1,0 & 19,8 \\
\hline \multicolumn{17}{|c|}{ IV. Граниты мигматитовой выплавки (AR, 7 проб)/IV. Granites of migmatitic melting (AR, 7 samples $)$} \\
\hline$\Phi У(5)$ & 1,0 & 1,0 & 0,9 & 1,0 & 0,2 & 2,5 & 1,1 & 1,2 & 0,9 & 1,3 & 0,8 & 0,5 & 0,8 & 3,1 & 1,0 & 1,2 \\
\hline ФИ (6) & 1,0 & 1,0 & 0,9 & 1,1 & 0,3 & 4,9 & 1,7 & 1,5 & 1,1 & 2,1 & 0,9 & 1,5 & 1,1 & 2,1 & 1,0 & 3,1 \\
\hline $\mathrm{X}(10)$ & 0,9 & 1,1 & 0,6 & 1,6 & 0,1 & 11 & 1,6 & 1,6 & \begin{tabular}{|l|l|}
0,9 \\
\end{tabular} & \begin{tabular}{|l|}
1,7 \\
\end{tabular} & \begin{tabular}{|c|}
0,6 \\
\end{tabular} & 0,9 & 1,5 & 3,7 & 1,0 & 6,9 \\
\hline $\mathrm{A}(9)$ & 1,0 & 1,1 & 0,8 & 1,0 & 7,6 & 17 & 1,0 & 1,7 & $\mid 1,0$ & 1,6 & 1,7 & 1,6 & 3,5 & 5,2 & 1,0 & 4,5 \\
\hline $\mathrm{T}(8)$ & 0,9 & 1,1 & 1,2 & 0,1 & 20 & 51 & 2,6 & 3,3 & 1,6 & 3,6 & 3,5 & 1,7 & 7,5 & 11 & 1,1 & 18,8 \\
\hline \multicolumn{17}{|c|}{$\begin{array}{c}\text { V.Дайковые фельзитовые умеренно щелочные биотитовые микрогранит-порфиры ( } P Z_{3}, 5 \text { проб) } \\
\text { V. Dike felsitic moderately alkaline biotitic microgranite porphyry }\left(P Z_{3}, 5 \text { samples }\right)\end{array}$} \\
\hline $\mathrm{X}(4)$ & 0,9 & 1,1 & 1,1 & 1,0 & 0,4 & 2,4 & 2,2 & 2,8 & 2,7 & \begin{tabular}{|l|}
1,6 \\
\end{tabular} & 3,8 & 3,1 & \begin{tabular}{|l|}
2,9 \\
\end{tabular} & 1,3 & 1,0 & 12,6 \\
\hline $\mathrm{A}(6)$ & 0,7 & 1,1 & 1,7 & 0,5 & 1,2 & \begin{tabular}{|l|l|}
4,0 \\
\end{tabular} & 3,4 & \begin{tabular}{|l|}
4,3 \\
\end{tabular} & \begin{tabular}{|l|l|}
4,3 \\
\end{tabular} & $\mid 1,8$ & 6,0 & \begin{tabular}{|l|}
4,3 \\
\end{tabular} & 4,1 & 2,9 & 1,0 & 27,0 \\
\hline $\mathrm{T}(6)$ & 0,7 & 1,2 & \begin{tabular}{|l|}
2,6 \\
\end{tabular} & 0,1 & 20,1 & \begin{tabular}{|l|l|}
4,9 \\
\end{tabular} & 4,5 & \begin{tabular}{|l|}
4,9 \\
\end{tabular} & \begin{tabular}{|l|}
3,1 \\
\end{tabular} & 5,5 & \begin{tabular}{l|l}
6,2 \\
\end{tabular} & \begin{tabular}{|l|}
4,6 \\
\end{tabular} & \begin{tabular}{|l|}
3,3 \\
\end{tabular} & 1,5 & 1,0 & 36,8 \\
\hline \multicolumn{17}{|c|}{$\begin{array}{l}\text { Кедровское месторождение/Kedrovskoe deposit } \\
\text { VI. Габбро муйского комплекса }\left(R_{3}, 1 \text { проба }\right) / \text { VI. Gabbro of muisk complex }\left(R_{3}, 1 \text { sample }\right)\end{array}$} \\
\hline $\mathrm{X}(4)$ & 0,9 & 1,0 & 1,5 & 2,4 & 24 & 2,2 & 0,6 & 0,9 & 1,2 & 0,7 & 1,3 & 0,8 & 1,7 & 0,9 & 1,0 & 10,6 \\
\hline $\mathrm{A}(2)$ & 0,9 & 1,0 & 1,9 & 1,6 & \begin{tabular}{|l|}
83 \\
\end{tabular} & 2,7 & 0,5 & 0,6 & 1,2 & 0,8 & 1,9 & 0,9 & 1,4 & 0,4 & 1,0 & 13,2 \\
\hline $\mathrm{T}(2)$ & 0,6 & 1,1 & 2,5 & 0,5 & 77 & 5,7 & 1,1 & 1,4 & 1,7 & $\mid 1,0$ & \begin{tabular}{l|l}
1,3 \\
\end{tabular} & 1,2 & 1,9 & 0,6 & 1,0 & 22,6 \\
\hline \multicolumn{17}{|c|}{$\begin{array}{l}\text { VII. Альмандин-двуслюдяные плагиоклазовые парагнейсы Кедровской очагово-купольной постройки (PZ, }(\text { п } 1 \text { проба }) \\
\text { VII.Almandine-two-mica plagioclase paragneisses of Kedrovskaya chamber-dome structure }\left(P Z_{3}, 1 \text { sample }\right)\end{array}$} \\
\hline$\Phi У(1)$ & 1,0 & 1,0 & 1,7 & 0,5 & 0,5 & 0,5 & 0,9 & 1,1 & 1,4 & 1,4 & 0,9 & 0,7 & 2,4 & - & 1,0 & 7,0 \\
\hline $\mathrm{X}(1)$ & 1,0 & 1,1 & 1,1 & 0,8 & 2,6 & 0,7 & 1,4 & 0,5 & 1,2 & 1,4 & \begin{tabular}{l|l}
1,1 \\
\end{tabular} & 0,6 & 1,7 & - & 1,0 & 6,0 \\
\hline $\mathrm{T}(1)$ & 0,5 & 0,5 & 1,3 & 0,1 & \begin{tabular}{|l|l|}
22 \\
\end{tabular} & 14 & 8,1 & 5,4 & 1,7 & 1,6 & \begin{tabular}{l|l}
2,0 & \\
\end{tabular} & 1,4 & 7,5 & - & 1,0 & 45,0 \\
\hline \multicolumn{17}{|c|}{$\begin{array}{l}\text { VIII. Квариевые диориты Кедровской очагово-купольной постройки (PZ, } 6 \text { проб) } \\
\left.\text { VIII. Quartz diorites of Kedrovskaya chamber-dome structure (PZ } Z_{3}, 6 \text { samples }\right)\end{array}$} \\
\hline $\mathrm{X}(1)$ & 1,0 & 1,0 & 0,8 & 1,0 & 1,5 & 4,8 & 1,0 & 1,1 & 1,2 & 0,7 & \begin{tabular}{l|l}
1,0 \\
\end{tabular} & 1,1 & \begin{tabular}{|l|l}
0,9 \\
\end{tabular} & 1,5 & 1,0 & 3,0 \\
\hline $\mathrm{A}(5)$ & 1,0 & 1,0 & 1,0 & 0,9 & 8,9 & 14 & 1,0 & 0,8 & 1,0 & \begin{tabular}{|l|l|}
0,3 \\
\end{tabular} & 0,9 & 0,8 & 0,9 & 1,3 & 1,0 & 6,0 \\
\hline $\mathrm{X}(16)$ & 1,0 & 1,0 & 1,0 & 1,0 & 11,1 & 10 & 1,0 & 1,0 & \begin{tabular}{|l|l|}
1,0 \\
\end{tabular} & 0,9 & 1,0 & 1,1 & \begin{tabular}{|l|l|}
1,0 \\
\end{tabular} & 1,5 & 1,0 & 4,0 \\
\hline $\mathrm{A}(6)$ & 0,9 & 0,9 & 1,2 & 0,9 & 32,7 & 22 & 1,3 & 1,5 & $\mid 1,6$ & 0,7 & 1,9 & 1,4 & $\mid 1,5$ & 1,1 & 1,0 & 12,0 \\
\hline $\mathrm{T}(1)$ & 0,5 & 0,8 & 1,4 & 0,2 & 428 & 48 & 3,2 & 3,4 & 2,7 & 4,2 & 2,7 & 3,4 & 2,6 & 0,3 & 1,1 & 41,0 \\
\hline \multicolumn{17}{|c|}{$\begin{array}{l}\text { IX. Дайковые квариевые диориты Кедровской очагово-купольной постройки (PZ, } 7 \text { проб) } \\
\left.\text { IX. Dike quartz diorites of Kedrovskaya chamber-dome structure ( } P Z_{3}, 7 \text { samples }\right)\end{array}$} \\
\hline $\mathrm{X}(17)$ & 1,0 & 1,0 & 1,0 & 1,0 & 5,4 & 9,1 & 1,0 & 0,9 & 1,1 & \begin{tabular}{|l|l}
0,6 \\
\end{tabular} & \begin{tabular}{l|l}
1,0 \\
\end{tabular} & 1,0 & 0,9 & 1,3 & 1,0 & 4,1 \\
\hline $\mathrm{A}(22)$ & 0,9 & 1,0 & 1,2 & 0,8 & 14,0 & 17 & 1,2 & 1,2 & 1,5 & 0,6 & 1,3 & 1,2 & 1,3 & 1,2 & 1,0 & 9,3 \\
\hline $\mathrm{T}(2)$ & 0,7 & 0,9 & 1,5 & 0,2 & 117 & \begin{tabular}{|l|}
34 \\
\end{tabular} & 2,4 & 2,7 & 2,4 & 1,6 & 2,1 & 2,4 & 2,3 & 1,0 & 1,0 & 29,7 \\
\hline \multicolumn{17}{|c|}{$\begin{array}{c}\text { Западное месторождение/Zapadnoe deposit } \\
\text { X. Габбро муйского комплекса }\left(R_{3}, 6 \text { проб)/X. Gabbro of muisk complex ( } R_{3}, 6 \text { samples) }\right.\end{array}$} \\
\hline $\mathrm{X}(3)$ & 0,9 & 0,9 & 1,2 & 1,1 & 1,0 & \begin{tabular}{|l|}
17 \\
\end{tabular} & 1,0 & 0,5 & 1,1 & \begin{tabular}{|l|l}
0,7 \\
\end{tabular} & \begin{tabular}{l|l}
0,9 & \\
\end{tabular} & \begin{tabular}{|l|}
0,9 \\
\end{tabular} & \begin{tabular}{|l|}
0,9 \\
\end{tabular} & 1,3 & 1,0 & \begin{tabular}{|l|}
8,6 \\
\end{tabular} \\
\hline $\mathrm{A}(1)$ & 0,9 & 0,9 & \begin{tabular}{|l|}
2,6 \\
\end{tabular} & 1,3 & 0,7 & 31 & 0,8 & \begin{tabular}{|l|l|}
0,4 \\
\end{tabular} & \begin{tabular}{|l|}
1,0 \\
\end{tabular} & \begin{tabular}{|l|}
0,2 \\
\end{tabular} & \begin{tabular}{|l|}
0,7 \\
\end{tabular} & \begin{tabular}{|l|}
0,8 \\
\end{tabular} & \begin{tabular}{|l|}
0,8 \\
\end{tabular} & 0,9 & 1,0 & 14,0 \\
\hline $\mathrm{T}(1)$ & 0,8 & 1,0 & $\mid 6,7$ & \begin{tabular}{|l|}
0,1 \\
\end{tabular} & 1,7 & \begin{tabular}{|l|}
42 \\
\end{tabular} & 1,2 & 0,8 & \begin{tabular}{|l|}
1,2 \\
\end{tabular} & \begin{tabular}{|l|}
0,2 \\
\end{tabular} & 1,1 & \begin{tabular}{|l|l|}
0,8 \\
\end{tabular} & \begin{tabular}{|l|}
0,7 \\
\end{tabular} & 1,5 & 1,1 & 23,5 \\
\hline
\end{tabular}


Продолжение табл. 1

Table 1

\begin{tabular}{|c|c|c|c|c|c|c|c|c|c|c|c|c|c|c|c|}
\hline \multirow{2}{*}{$\begin{array}{l}\text { Минералого-петрохимические зоны и подзоны (число проб) } \\
\text { Mineral-Petrochemic zones and subzones (number of samples) }\end{array}$} & \multicolumn{14}{|c|}{ Химические элементы/Chemical elements } & \multirow{2}{*}{$\Delta$} \\
\hline & $\mathrm{Si}$ & $\mathrm{Al}$ & \begin{tabular}{|l|l|}
$\mathrm{K}$ & $\mathrm{Na}$ \\
\end{tabular} & $\mathrm{S}^{*}$ & $\mathrm{C}_{\mathrm{к} \tilde{.} .}$ & $\mathrm{Ca}$ & $\mathrm{Mg}$ & $\mathrm{Fe}^{2+}$ & $\mathrm{Fe}^{3+}$ & $\mathrm{Ti}$ & $\mathrm{Mn}$ & $\mathrm{P}$ & $\mathrm{H}^{+}$ & 0 & \\
\hline \multicolumn{16}{|c|}{ XI.Дайковые долериты ( $\mathrm{PZ}_{3}, 8$ проб) /XI. Dike dolerites (PZ $Z_{3}, 8$ samples) } \\
\hline $\mathrm{X}(9)$ & 0,9 & 0,9 & \begin{tabular}{|l|l|l|}
2,2 & 1,0 \\
\end{tabular} & 0,8 & 10 & 0,9 & 0,8 & 0,9 & 0,5 & 0,9 & 0,8 & 0,6 & 0,9 & 1,0 & 11,0 \\
\hline $\mathrm{A}(2)$ & 0,8 & 0,9 & \begin{tabular}{|l|l|}
5,4 & 0,5 \\
\end{tabular} & 1,3 & 15 & 0,8 & 0,9 & 1,1 & 0,1 & 0,9 & 0,8 & 0,6 & 1,0 & 1,1 & 20,0 \\
\hline $\mathrm{T}(5)$ & 0,8 & 0,8 & \begin{tabular}{|l|l|}
6,5 & 0,1 \\
\end{tabular} & 1,6 & 16 & 0,9 & 1,0 & 1,0 & 0,4 & 0,8 & 0,6 & 0,5 & 1,3 & 1,1 & 21,0 \\
\hline \multicolumn{16}{|c|}{$\begin{array}{l}\text { Петелинское квариево-жильное поле/Petelinskoe quartz-vein field } \\
\text { е порфиры келянской свиты }\left(R_{3}, 5 \text { проб)/XII. Cover quartz porphyry of kelyanskaja suite }\left(R_{3}, 5 \text { samples }\right)\right.\end{array}$} \\
\hline $\mathrm{X}(4)$ & 1,0 & 1,0 & \begin{tabular}{|l|l|}
0,9 & 1,0 \\
\end{tabular} & 2,3 & 3,0 & 0,8 & 0,6 & 0,8 & 1,0 & 0,9 & 1,1 & 0,9 & 0,7 & 1,0 & 3,3 \\
\hline $\mathrm{A}^{*}(6)$ & 1,1 & 1,0 & \begin{tabular}{|l|l|}
1,1 & 0,9 \\
\end{tabular} & 2,4 & 4,6 & 0,6 & 0,5 & 0,8 & 0,4 & 0,9 & 0,7 & 0,6 & 0,6 & 1,0 & 6,8 \\
\hline $\mathrm{A} * *(3)$ & 0,8 & 1,1 & \begin{tabular}{|l|l|}
2,1 & 0,5 \\
\end{tabular} & 3,4 & 17 & 1,7 & 2,6 & 1,8 & 0,8 & 1,3 & 1,7 & 1,6 & 1,7 & 1,0 & 20,3 \\
\hline \multicolumn{16}{|c|}{ ХІІІ. Покровные базальтовые порфириты келянской свиты $\left(R_{3}, 2\right.$ nробы $) / X I I I$. Cover basalt porphyrites of kelyanskaja suite $\left(R_{3}, 2\right.$ samples $)$} \\
\hline $\mathrm{X}(4)$ & 0,9 & 0,9 & \begin{tabular}{|l|l|l|}
1,6 & 0,9 \\
\end{tabular} & 2,2 & 16 & 0,7 & 0,8 & 1,0 & 0,4 & 0,9 & 0,7 & 0,8 & 0,8 & $3 \mid 1,0$ & 11,1 \\
\hline $\mathrm{A}(2)$ & 0,8 & 0,8 & \begin{tabular}{|l|l|}
3,3 & 0,6 \\
\end{tabular} & 38 & 25 & 0,8 & 0,6 & 1,5 & 0,5 & 1,8 & 1,2 & 4,2 & 1,0 & 1,1 & 23,9 \\
\hline $\mathrm{T}(1)$ & 0,6 & 0,9 & \begin{tabular}{|l|l|}
5,2 & 0,1 \\
\end{tabular} & 19 & 29 & 1,4 & 0,8 & 0,9 & 0,6 & 0,8 & 0,8 & 0,5 & 2,3 & 1,1 & 29,4 \\
\hline \multicolumn{16}{|c|}{$\begin{array}{c}\text { Богодиканское месторождение/Bogodikanskoe deposit } \\
X I V . \text { Дайковые долериты }\left(\mathrm{PZ}_{3}, 16 \text { проб) /XIV. Dike dolerites }\left(\mathrm{PZ}_{3}, 16 \text { samples }\right)\right.\end{array}$} \\
\hline $\mathrm{X}(4)$ & 0,9 & 0,9 & $1,3 \mid 0,8$ & 0,8 & 29 & 0,8 & 1,1 & 0,9 & 0,6 & 0,8 & 0,9 & 0,7 & 1,3 & 1,0 & 12,5 \\
\hline $\mathrm{A}(1)$ & 0,8 & 0,7 & \begin{tabular}{|l|l|}
2,2 & 0,6 \\
\end{tabular} & 0,6 & 51 & 0,8 & 0,9 & 1,1 & 0,3 & 0,9 & 1,0 & 0,8 & 0,7 & 1,1 & 20,7 \\
\hline $\mathrm{T}(2)$ & 0,8 & 0,9 & \begin{tabular}{|l|l|}
3,1 & 0,1 \\
\end{tabular} & 0,9 & 42 & 0,9 & 1,0 & 1,0 & 0,3 & 0,7 & 0,8 & 0,6 & 1,4 & 1,1 & 19,3 \\
\hline \multicolumn{16}{|c|}{$\begin{array}{l}\text { Верхне-Сакуканское месторождение/Verkhne-Sakukanskoе deposit } \\
X V . \text { Квариевые диориты и квариевые мониониты кодарского комплекса }\left(P R_{1}, 6 \text { проб) }\right. \\
\text { XV.Quartz diorites and quartz monzonites of kodar complex }\left(P R_{1}, 6 \text { samples }\right)\end{array}$} \\
\hline$\Phi У(5)$ & 1,0 & 0,9 & \begin{tabular}{|l|l|l|}
1,0 & 0,8 \\
\end{tabular} & 1,4 & 6,1 & 0,8 & 1,1 & 1,1 & 1,2 & 1,1 & 1,1 & 1,0 & 1,4 & 1,0 & 3,7 \\
\hline $\mathrm{X}(1)$ & 1,0 & 0,9 & \begin{tabular}{|l|l|}
0,8 & 0,8 \\
\end{tabular} & 3,2 & 19 & 0,9 & 1,0 & 0,9 & 0,6 & 1,0 & 1,0 & 0,9 & 1,7 & 1,0 & 6,0 \\
\hline $\mathrm{A}(4)$ & 0,9 & 1,0 & \begin{tabular}{|l|l|}
1,4 & 0,6 \\
\end{tabular} & 1,7 & 32 & 1,2 & 1,3 & 0,8 & 0,9 & 1,1 & 1,3 & 1,0 & 1,6 & 1,0 & 9,6 \\
\hline $\mathrm{T}(1)$ & 0,8 & 0,9 & \begin{tabular}{|l|l|}
1,1 & 0,1 \\
\end{tabular} & 3,4 & 79 & 2,0 & 5,2 & 1,2 & 0,7 & 0,8 & 2,7 & 0,9 & 2,2 & 1,1 & 26,6 \\
\hline \multicolumn{16}{|c|}{$\begin{array}{r}\text { Регионально-метаморфизованные углеродистые терригенные сланцевые толщи/Regional metamorphosed carbonaceous terrigenous slates terranes } \\
\text { Кедровское месторождение/Kedrovskoe deposit } \\
\text { XVI. Углеродистые мусковит-биотитовые полевошпат-квариевые песчано-алевро-сланцы кедровской свиты (R, } 10 \text { проб), } \\
\text { залежь метасоматитов типа «слоеного пирога», мощность } 220 \mathrm{~m}\end{array}$} \\
\hline$\Phi И(4)$ & 1,0 & 1,1 & \begin{tabular}{|l|l|l|}
1,3 & 0,8 \\
\end{tabular} & - & 1,9 & 0,9 & 1,5 & 1,4 & 1,5 & 1,1 & 0,9 & 1,2 & 1,3 & $3 \mid 1,0$ & 6,2 \\
\hline $\mathrm{X}(51)$ & 0,9 & 1,0 & \begin{tabular}{|l|l|}
0,9 & 0,7 \\
\end{tabular} & 62 & 8,7 & 1,9 & 1,8 & 1,5 & 1,0 & 1,2 & 1,7 & 0,6 & 1,9 & 1,0 & 8,1 \\
\hline $\mathrm{A}(73)$ & 1,0 & 1,0 & \begin{tabular}{|l|l|}
1,1 & 0,8 \\
\end{tabular} & 67 & 13 & 1,9 & 1,0 & 1,3 & 0,7 & 1,0 & 1,5 & 0,4 & 1,3 & \begin{tabular}{|l|l|}
3 & 1,0 \\
\end{tabular} & 6,6 \\
\hline $\mathrm{T}(8)$ & 0,9 & 1,0 & \begin{tabular}{|l|l|}
1,5 & 0,1 \\
\end{tabular} & 128 & 20 & 3,4 & 1,9 & 1,3 & 1,0 & 1,4 & 1,8 & 1,3 & 1,9 & 1,0 & 16,2 \\
\hline \multicolumn{16}{|c|}{$\begin{array}{r}\text { XVII. Углеродистые мусковит-биотитовые полевошпат-квариевые песчано-алевро-сланцы кедровской свиты ( } R_{3}, 1 \text { проба), ореол в обрамле- } \\
\text { нии золотоносной квариевой жильl } \\
\text { XVII. Carbonaceous muscovite-biotitic feldspar-quartz sandstone-aleuro-slates of kedrovskaya suite }\left(R_{3}, 1 \text { sample }\right), \\
\text { the halo in the frame of gold-bearing quartz vein }\end{array}$} \\
\hline $\mathrm{A}(1)$ & 0,8 & 1,0 & \begin{tabular}{|l|l|}
3,5 & 0,7 \\
\end{tabular} & + & 20 & 1,3 & 12 & 3,8 & 4,4 & 1,8 & 4,7 & 4,0 & 6,6 & 1,0 & 18,0 \\
\hline $\mathrm{T}(1)$ & 0,6 & 1,1 & \begin{tabular}{|l|l|}
5,5 & 0,1 \\
\end{tabular} & + & 70 & 9,8 & 19 & 5,5 & 2,3 & 1,7 & 4,5 & 7,7 & 15 & 1,0 & 43,0 \\
\hline \multicolumn{16}{|c|}{$\begin{array}{l}\text { Каралонское месторождение/Karalonskoе dеровіt } \\
\text { XVIII. Углеродистые мусковит-биотитовые полевошпат-квариевые песчано-алевро-сланиы водораздельной свиты }\left(R_{3}, 2 \text { пробы }\right) \\
\text { XVIII. Carbonaceоus тиscovite-biotitic feldspar-quartz sandstone-aleuro-slates of vodorazdelnaya suite }\left(R_{3}, 2 \text { samples }\right)\end{array}$} \\
\hline$\Phi И(8)$ & 0,8 & 1,0 & \begin{tabular}{|l|l|}
0,7 & 0,8 \\
\end{tabular} & 2,1 & 4,5 & 3,2 & 4,0 & 2,2 & 1,9 & 1,4 & 2,2 & 0,7 & 1,2 & 1,0 & 17,9 \\
\hline $\mathrm{X}^{*}(7)$ & 0,7 & 1,0 & \begin{tabular}{|l|l|}
1,2 & 0,5 \\
\end{tabular} & 2,7 & 8,2 & 3,8 & 3,7 & 3,0 & 1,6 & 1,5 & 3,2 & 0,3 & 1,0 & 1,0 & 24,8 \\
\hline $\mathrm{X} * *(6)$ & 0,7 & 1,1 & \begin{tabular}{|l|l|}
1,2 & 0,5 \\
\end{tabular} & 6,5 & 7,4 & 3,4 & 3,7 & 3,1 & 2,0 & 1,8 & 3,0 & 0,3 & 1,6 & 1,0 & 26,4 \\
\hline $\begin{array}{ll}\mathrm{T}(3) \\
\end{array}$ & 0,9 & 1,1 & \begin{tabular}{|l|l|}
2,2 & 0,1 \\
\end{tabular} & 44 & 3,9 & 1,7 & 2,7 & 2,6 & 1,0 & 1,6 & 1,0 & 0,3 & 1,7 & 1,0 & 20,5 \\
\hline \multicolumn{16}{|c|}{$\begin{array}{l}\text { Месторождение Чертово Корыто/Сhertovo Koryto deровit } \\
\text { ХІХ. Углеродистые мусковит-биотитовые полевошпат-квариевые крупнозернистые алевро-сланцы михайловской свиты (PR, } 3 \text { пробы }) \\
\text { ХІХ. Carbonaceоus тиscovite-biotitic feldspar-quartz big-grain aleuro-slates of mikhajlovskaya suite }\left(P R_{1}, 3 \text { samples }\right)\end{array}$} \\
\hline $\begin{array}{l}\mathrm{y}(2) 1,0 \\
\end{array}$ & 1,0 & 1,0 & \begin{tabular}{|l|l|}
0,9 & 0,7 \\
\end{tabular} & 0,9 & 1,5 & 1,2 & 1,0 & 1,3 & 1,1 & 1,0 & 1,0 & - & 1,0 & 2,9 & \\
\hline $\mathrm{X}(8)$ & 0,8 & 0,7 & \begin{tabular}{|l|l|}
0,7 & 0,3 \\
\end{tabular} & 2,2 & 15 & 13 & 2,0 & 1,7 & 1,1 & 6,4 & 6,6 & 9,4 & - & 1,1 & 29,7 \\
\hline $\mathrm{T}(1)$ & 0,6 & 0,7 & \begin{tabular}{|l|l|}
0,9 & 0,1 \\
\end{tabular} & 1,0 & 29 & 20 & 2,7 & 1,3 & 0,1 & 6,7 & 22 & 10 & - & 1,1 & 43,4 \\
\hline \multicolumn{16}{|c|}{$\begin{array}{c}\text { ХХ. Углеродистые мусковит-биотитовые полевошпат-квариевые мелкозернистые песчано-сланиы михайловской свиты (PR, } 3 \text { пробы }) \\
\text { ХХ. Carbonaceоus mиscovite-biotitic feldspar-quartz fine-grain sandstone-slates of mikhaylovskaja suite (PR, } 3 \text { samples) }\end{array}$} \\
\hline $\begin{array}{l}\mathrm{V}(1) \\
\end{array}$ & 1,0 & 1,0 & \begin{tabular}{|l|l|l|}
0,7 & 1,8 \\
\end{tabular} & 2,8 & 1,4 & 1,3 & 1,1 & 1,0 & 0,8 & 1,3 & 2,0 & 0,7 & - & 1,0 & 3,5 \\
\hline $\mathrm{y}(3)$ & 1,0 & 1,1 & \begin{tabular}{|l|l|}
0,8 & 1,1 \\
\end{tabular} & 2,3 & 2,0 & 1,8 & 2,2 & 1,3 & 1,7 & 1,2 & 2,5 & 1,0 & - & 1,0 & 6,5 \\
\hline $\mathrm{X}(6)$ & 0,6 & 1,0 & \begin{tabular}{|l|l|}
0,8 & 0,3 \\
\end{tabular} & 5,3 & 20 & 15 & 4,3 & 2,6 & 1,3 & 9,2 & 19 & 9,9 & - & 1,0 & 34,9 \\
\hline $\mathrm{T}(1)$ & 0,7 & 0,9 & \begin{tabular}{|l|l|}
0,9 & 0,1 \\
\end{tabular} & 1,1 & 21 & 14 & 3,6 & 2,1 & 2,8 & 8,9 & \begin{tabular}{|l|}
37 \\
\end{tabular} & 9,7 & - & 1,0 & 32,5 \\
\hline
\end{tabular}


Окончание табл. 1

Table 1

\begin{tabular}{|c|c|c|c|c|c|c|c|c|c|c|c|c|c|c|c|c|}
\hline \multirow{2}{*}{$\begin{array}{l}\text { Минералого-петрохимические зоны и подзоны (число проб) } \\
\text { Mineral-Petrochemic zones and subzones (number of samples) }\end{array}$} & \multicolumn{15}{|c|}{ Химические элементы/Chemical elements } & \multirow{2}{*}{$\Delta$} \\
\hline & $\mathrm{Si}$ & $\mathrm{Al}$ & $\mathrm{K}$ & $\mathrm{Na}$ & S* & $\mathrm{C}_{\text {кб. }}$. & $\mathrm{Ca}$ & $\mathrm{Mg}$ & $\mathrm{Fe}^{2+}$ & $\mathrm{Fe}^{3+}$ & $\mathrm{Ti}$ & $\mathrm{Mn}$ & $\mathrm{P}$ & $\mathrm{H}^{+}$ & 0 & \\
\hline \multicolumn{17}{|c|}{$\begin{array}{l}\text { XXI. Углеродистые мусковит-биотитовые полевошпат-квариевые разнозернистые песчано-сланцы михайловской свиты (PR, } 3 \text { пробы) } \\
\text { XXI. Carbonaceous muscovite-biotitic feldspar-quartz various-grain sandstone-slates of mikhaylovskaja suite (PR, } 3 \text { samples) }\end{array}$} \\
\hline $\mathrm{y}(1)$ & 1,0 & 1,0 & 1,7 & 0,3 & 12 & 1,1 & 0,6 & 2,1 & 1,6 & 1,9 & 1,3 & 1,0 & 0,5 & - & 1,0 & 7,9 \\
\hline $\mathrm{X}(4)$ & 0,7 & 0,9 & 1,0 & 0,2 & 17 & 15 & 6,1 & 5,2 & 3,4 & 1,8 & 9,4 & 7,0 & 5,5 & - & 1,0 & 31,4 \\
\hline $\mathrm{T}(1)$ & 0,5 & 0,7 & 0,9 & 0,1 & 67 & 33 & 14 & 7,9 & 3,5 & 5,9 & 5,9 & 47 & 7,4 & - & 1,0 & 55,6 \\
\hline
\end{tabular}

Примечание. I-ХХІ - исходные породы вне и в подзоне слабого изменения фронтальной зоны. Минеральные зоны и подзоны околорудных метасоматических ореолов: ФУ, ФИ - подзоны умеренного и интенсивного изленения фронтальной зоны; У, Х, $A, T$ - углеродистая, Хлоритовая (эпидотовая, эпидот-хлоритовая), альбитовая и тыловая (березитовая, лиственитовая) зоны, *- улеренного, ** - интенсивного изленения. $\mathrm{S}^{*}$ - сера сульфидная, $\mathrm{H}^{+}$- водород воды $\mathrm{H}_{2} \mathrm{O}^{+} . \Delta-$ - удельная масса перемещенного (привнесенного и вынесенного) вещества в отношении к массе вещества исходной породы в стандартном геометрическом объеме $10000 \AA^{3}$. Жирныл шрифтом выделены контрастные $(К P>1,5)$ аномалии хилических элементов. Петрохилические расчеты выполнены по обвемно-атомному методу. Полные химические анализы горных пород выполнены в Центральной лаборатории ПГО «ЗапСибгеология» (г. Новокузнецк) под руководством И.А. Дубровской и в Западно-Сибирском Испытательном Центре (г.Новокузнеик) под руководством Г.Н. Юминовой.

Note. I-XXI are the initial rocks outside and in subzone of weak alteration of frontal zone. Mineral zones and subzones of near-ore metasomatic haloes: $\Phi У, \Phi И$ are the subzones of moderate and intensive alteration of frontal zone; $У, X, A, T$ are the carbonaceous, chloritic (epidotic, epidotchloritic), albitic and rear (beresitic, listvenitic) zones, *-moderate, **-intensive alteration. $S *$ is the sulfide sulphur, $H^{+}$is the hydrogen of water $\mathrm{H}_{2} \mathrm{O}^{+} . \Delta$ is the specific weight of the removed (added and carried out) substance in relation to the weight of the initial rock substance in standard geometric measurement $10000 \AA^{3}$. Contrast $(C D>1,5)$ anomalies of chemical elements are put in bold type. Petrochemical calculation are carried out by volume-atomic method. Complete chemical silicate analysis of rocks are carried out in Central laboratory of the PGA «Zapsibgeologia» (Novokuznetsk) under the leadership of I.A. Dubrovskaya and in Western-Siberian Test Centre under the leadership of G.N. Yuminova.

минеральными ассоциациями метасоматитов в обычно крупнообъемных периферийных минералого-петрохимических зонах околорудных ореолов-колонок средне-низкотемпературной березитовой формации не в процессе и результате регионального метаморфизма гидратации фации зеленых сланцев, а в мезотермальных околорудных метасоматических процессах, подобно тому, как это происходит в обрамлении залежей высокотемпературных известковых, магнезиальных скарнов, грейзенов, низкотемпературных аргиллизитов. Эти материалы также демонстрируют всеобъемлющую аутентичность структуры (минералогопетрохимической зональности), составов околорудных сочетающих березитовую и пропилитовую формации, образованных в кристаллическом и черносланцевом субстрате метасоматических ореолов-колонок, отражающую в том и другом субстрате вещественно-генетическую однородность процессов породо-, рудообразования.

\section{Минералого-петрохимическая зональность околорудного метасоматического ореола золоторудного месторождения Сухой Лог}

Для объективной оценки условий образования в толщах черных сланцев золотого оруденения «сухоложского типа» [14] требуется вернуть в научный оборот «забытые» современниками материалы предшественников, полученные в шестидесятые-семидесятые годы прошлого столетия во времена детальной разведки месторождения Сухой Лог и максимальной доступности его для изучения.

Согласно результатам ранних, до открытия и детальной разведки месторождения, исследований коренной золотоносности в бассейне р. Бодай- бо Ленского района, выполненных С.Д. Шером [63], черные сланцы - разнозернистые полимиктовые углеродистые песчаники - в обломочной фракции сложены зернами кварца (до $40 . .50$ об. \%), плагиоклазов (до $15 . .20$ об. \% ), обыкновенной роговой обманки (до 5 об. \%) с примесью обломков диабазов, альбитофиров, эпидозитов, кварцитов, сцементированных (цемента до $10 . .15$ об. \%) более мелкозернистыми агрегатами хлорита, серицита, эпидота, пирротина. В направлении к оруденению плагиоклазы, хлорит полностью замещены серицитом. В обрамлении золоторудных жил измененные породы осветлены, в них образованы многочисленные кристаллы-ромбоэдры анкерита и более крупные порфиробласты-ромбоэдры сидерита, метакристаллы пирита, оторочки рутила вокруг псевдоморфных выделений кварца. По данным петрохимических пересчетов в процессе околорудных изменений пород в последние поступили калий, восстановленная сера и углекислота, из пород удалены натрий и частично кремний. С.Д. Шер квалифицировал процесс как лиственитизацию.

По данным И.В. Коновалова [64], околорудный метасоматический ореол в обрамлении золотоносной кварцевой жилы месторождения Сухой Лог включает внешнюю, 1-ю, 2-ю промежуточные и внутреннюю минеральные зоны. Слабо измененные песчаники во внешней зоне сложены кварцем, плагиоклазом (андезином), микроклином, обыкновенной роговой обманкой с примесью эпигенетических минералов этапа околорудного метасоматизма - хлорита, эпидота, альбита, серицита, доломита, сидерита. В составе 1-ой промежуточной зоны участвуют кварц, серицит, доломит, пистомезит, альбит, реликтовые андезин, микроклин, 
2-ой промежуточной зоны - кварц, серицит, пистомезит, анкерит, альбит, пирит, реликтовый андезин. Внутренняя зона полиминеральна и сложена агрегатом кварца, серицита, кальцита, анкерита, пирита. В процессе метасоматизма из породы вынесены (в расчете на 100 куб. см) кремнезем (19 г), окись натрия $(1,06$ г), поступили в породу оксид калия $(2,06$ г), углекислота $(13,73$ г), восстановленная сера.

На дальней периферии обрамляющих рудные залежи зональных метасоматических ореолов месторождения Сухой Лог углеродистые песчаносланцы, алевро-сланцы позднерифейских догалдынской и хомолхинской свит во внешней (биотитовой) зоне регионального метаморфизма нагревания сложены в составе обломочной фракции кварцем (до 60 об. \%), полевыми шпатами с примесью хлоритизированного биотита, эпигенетических эпидота, серицита, мусковита, кальцита, доломита, «углистого» вещества, пирита, акцессорных циркона, сфена, апатита, рутила, магнетита [65-67]. В рудных зонах тонкосланцевые метасоматиты, состоящие из серицита, "углистого» вещества, крупных (до 5 мм) удлиненных порфиробластов и гнездовых скоплений железистого карбоната, гнезд, прожилков пирита и кварца, чередуются с массивными метасоматитами, сложенными кварцем (до 80 об. \%), серицитом, альбитом, хлоритом при участии скоплений доломита, железистого карбоната, пирита. Кварцевые прожилки нередко имеют расплывчатые контакты, в них прослеживается продолжение поверхностей сланцеватости по положению чешуек серицита в кварце, что свидетельствует о метасоматическом происхождении прожилков. Метакристаллы и скопления карбонатов содержат реликты сланцев. Внутренняя (тыловая) зона метасоматического ореола включает ассоциацию кварца, серицита, магнезиально-железистых карбонатов, пирита, рутила, лейкоксена, апатита. Рутил в метасоматитах образует концентрические каемки вокруг будиноподобных скоплений кварца, карбонатов, хлорита. Изменение химических составов песчаников обеих свит при околорудном метасоматизме выражается (табл. 2) соответственно в выносе из пород кремнезема (содержание в метасоматите снижается до 46,06 мас. \% против 62,23 мас. \% в песчанике и до 52,0 мас. \% против 80,09 мас. \%), привносе в породы окиси калия (до 3,60 мас. \% против 1,50 мас. \%), углекислоты в расчете на $\mathrm{CO}_{2}$ (до 5,28 мас. \% против 4,64 мас. \% и до 14,08 мас. \% против 0,32 мас. \%), окиси магния (до 4,0 мас. \% против 2,10 мас. \% и до 6,60 мас. \% против 1,12 мас. \%), закиси восстановленного железа (до 6,47 мас. \% против 2,66 мас. \% и до 14,08 мас. \% против 2,02 мас. \%), окиси титана (до 0,94 мас. \% против 0,55 мас. \% и до 0,36 мас. \% против 0,08 мас. \%). Поступление в породы фосфора зафиксировано участием в составе золотоносных кварцевых жил голубого и розового апатита [68]. Упомянутые авторы публикаций квалифицируют околорудный калиево-сернисто-углекислотный метасоматический процесс при образовании месторождения Сухой Лог как березитизацию-лиственитизацию.

Рудовмещающий метасоматический ореол на Западном участке месторождения Сухой Лог в разведанной его части сложен метасоматитами промежуточных хлоритовой и альбитовой минеральных зон сводной зональной метасоматической колонки (табл. 3), включающей также фронтальную и тыловую минеральные зоны, составы которых заимствованы из материалов предшественников по недоступной для изучения в последние годы после разведки центральной части месторождения [63-67], и подробно описанных в [69]. Минеральные составы тыловых - альбитовой и собственно тыловой березитовой - минеральных зон рудовмещающего метасоматического ореола месторождения подчеркиваются также результатами минералого-геохимического изучения рудной технологической пробы [70], минеральный состав которой отвечает составу березита, но с примесью альбита типоморфного минерала смежной с березитовой альбитовой зоны при отсутствии хлорита - вестника более фронтальной хлоритовой зоны. В технологической пробе, сочетающей в своем составе минеральные ассоциации березитовой и альбитовой минеральных зон, отмечены приведенные выше изменения химического состава смеси метасоматических минералов обеих минеральных зон, вмещающих руды, - пониженное против исходных песчано-сланцев, алевро-сланцев догалдынской и хомолхинской свит содержание кремнезема, но повышенное - магния, железа, углекислоты, восстановленной серы, углеродистого вещества.

Таблица 2. Химические составы песчано-сланиев и апосланцевых метасоматитов рудовмещающего метасоматического ореола месторождения Сухой Лог [66]

Table 2. Chemical compositions of the sandstones and formed in them metasomatites of ore containing metasomatic aureole of Sukhoy Log deposit [66]

\begin{tabular}{|c|c|c|c|c|c|c|c|c|c|c|c|c|c|c|c|}
\hline \multirow{2}{*}{$\begin{array}{c}\text { Минеральные зоны } \\
\text { Mineral zones }\end{array}$} & \multicolumn{14}{|c|}{ Содержание, мac. \%/Content, wt. \% } & \multirow{2}{*}{$\Sigma$} \\
\hline & $\mathrm{SiO}_{2}$ & $\mathrm{Al}_{2} \mathrm{O}_{3}$ & $\mathrm{~K}_{2} \mathrm{O}$ & $\mathrm{Na}_{2} \mathrm{O}$ & $\mathrm{CO}_{2}$ & $\mathrm{CaO}$ & $\mathrm{MgO}$ & $\mathrm{FeO}$ & $\mathrm{Fe}_{2} \mathrm{O}_{3}$ & $\mathrm{TiO}_{2}$ & $\mathrm{P}_{2} \mathrm{O}_{5}$ & $\mathrm{MnO}$ & $\mathrm{H}_{2} \mathrm{O}^{+}$ & $\mathrm{H}_{2} \mathrm{O}^{-}$ & \\
\hline \multicolumn{16}{|c|}{ Догалдынская свита, $\mathrm{R}_{3}$ /Dogaldynskaya suite, $\mathrm{R}_{3}$} \\
\hline Фронтальная/Frontal & 62,23 & 12,35 & 1,50 & 3,50 & 4,64 & 2,66 & 2,10 & 2,66 & 5,04 & 0,55 & 0,17 & 0,12 & 2,12 & 0,08 & 99,72 \\
\hline Альбитовая/Albitic & 46,06 & 22,50 & 3,60 & 3,64 & 5,28 & 0,56 & 4,00 & 6,47 & 1,84 & 0,94 & 0,30 & 0,06 & 4,78 & 0,24 & 100,27 \\
\hline \multicolumn{16}{|c|}{ Хомолхинская свита, $R_{3} /$ Khomolkhinskaya suite, $R_{3}$} \\
\hline Фронтальная/Frontal & 80,09 & 5,65 & 1,07 & 0,67 & 0,32 & 1,40 & 1,12 & 2,02 & 3,12 & 0,08 & 0,58 & 0,06 & 3,38 & - & 99,56 \\
\hline Альбитовая/Albitic & 52,00 & 5,65 & 1,13 & 0,57 & 14,08 & 0,84 & 6,60 & 14,08 & 2,86 & 0,36 & 0,27 & 0,31 & 0,70 & 0,22 & 99,67 \\
\hline
\end{tabular}


Таблица 3. Обобщенная схема минеральной зональности рудовмещающего метасоматического ореола месторождения Сухой Лог

Table 3. Generalized plan of mineral zoning of ore containing metasomatic aureole of the Sukhoy Log deposit

\begin{tabular}{|c|c|}
\hline $\begin{array}{l}\text { Минеральные зоны, горные породы, свиты } \\
\text { Mineral zones, rocks, suites }\end{array}$ & $\begin{array}{l}\text { Минеральный состав } \\
\text { Mineral composition }\end{array}$ \\
\hline $\begin{array}{l}\text { Фронтальная [63] Песчаники } \\
\text { Frontal Sandstones }\end{array}$ & $\begin{array}{l}\text { Кварц, серицит, альбит, эпидот, хлорит, пирротин. Исходные: кварц, олигоклаз, роговая обманка } \\
\text { Quartz, sericite, albite, epidote, chlorite, pyrrhotite. Initial: quartz, oligoclase, amphibole }\end{array}$ \\
\hline $\begin{array}{l}\text { Фронтальная [64] Песчаники } \\
\text { Frontal Sandstones }\end{array}$ & $\begin{array}{l}\text { Кварц, серицит, альбит, доломит, сидерит, эпидот, хлорит. Исходные: кварц, андезин, микроклин, } \\
\text { роговая обманка } \\
\text { Quartz, sericite, albite, dolomite, siderite, epidote, chlorite. Initial: quartz, andesine, microcline, } \\
\text { amphibole }\end{array}$ \\
\hline $\begin{array}{l}\text { Фронтальная [66] Песчано-, алевросланцы } \\
\text { догалдынской и хомолхинской свит } \\
\text { Frontal sandstone-, aleuroshales of the do- } \\
\text { galdynskaja, chomolchinskaja suites }\end{array}$ & $\begin{array}{l}\text { Кварц, серицит, кальцит, доломит, эпидот, хлорит Исходные: кварц, полевые шпаты, кероген, му- } \\
\text { сковит, биотит } \\
\text { Quartz, sericite, calcite, dolomite, epidote, chlorite Initial: quartz, feldspars, kerogen, muscovite, biotite }\end{array}$ \\
\hline $\begin{array}{l}\text { Хлоритовая [69] Песчано-, алевросланцы } \\
\text { имняхской и хомолхинской свит } \\
\text { Chloritic sandstone-, aleuroshales of the im- } \\
\text { nyachskaya, chomolchinskaya suites }\end{array}$ & $\begin{array}{l}\text { Кварц, серицит, рутил, лейкоксен, магнетит, пирит } \pm \text { кальцит }+ \text { анкерит } \pm \text { сидерит }+ \text { альбит }+ \\
\underline{\text { хлорит }} \\
\text { Quartz, sericite, rutile, leucoxene, magnetite, pyrite } \pm \text { calcite }+ \text { ankerite } \pm \text { siderite }+ \text { albite }+\underline{\text { chlorite }}\end{array}$ \\
\hline $\begin{array}{l}\text { Альбитовая [69] } \\
\text { Albitic }\end{array}$ & $\begin{array}{l}\text { Кварц, серицит, рутил, лейкоксен, магнетит, пирит } \pm \text { кальцит + анкерит } \pm \text { сидерит + альбит } \\
\text { Quartz, sericite, rutile, leucoxene, magnetite, pyrite } \pm \text { calcite }+ \text { ankerite } \pm \text { siderite }+\underline{\text { albite }}\end{array}$ \\
\hline $\begin{array}{l}\text { Tыловая [63] } \\
\text { Rear }\end{array}$ & $\begin{array}{l}\text { Кварц, серицит, рутил, пирит, анкерит, сидерит } \\
\text { Quartz, sericite, rutile, pyrite, ankerite, siderite }\end{array}$ \\
\hline $\begin{array}{l}\text { Тыловая [64] } \\
\text { Rear }\end{array}$ & $\begin{array}{l}\text { Кварц, серицит, кальцит, анкерит } \\
\text { Quartz, sericite, calcite, ankerite }\end{array}$ \\
\hline $\begin{array}{l}\text { Tыловая [66] } \\
\text { Rear }\end{array}$ & $\begin{array}{l}\text { Кварц, серицит, рутил, лейкоксен, пирит, Mg-Fе-карбонаты, апатит } \\
\text { Quartz, sericite, rutile, leucoxene, pyrite, Mg-Fe-carbonates, apatite }\end{array}$ \\
\hline $\begin{array}{l}\text { Tыловая [67] } \\
\text { Rear }\end{array}$ & $\begin{array}{l}\text { Кварц, мусковит, пирит, анкерит, сидерит } \\
\text { Quartz, muscovite, pyrite, ankerite, siderite }\end{array}$ \\
\hline
\end{tabular}

Примечание. Подчеркнуты минералы, исчезающие в более тыловых зонах.

Note. The minerals disappearing in more rear zones are underlined.

Таким образом, в результатах изучения предшественниками околорудных метасоматических преобразований вмещающих залежи прожилкововкрапленных руд и золоторудные кварцевые жилы черных сланцев в золоторудном месторождении Сухой Лог зафиксированы типовые черты мезотермального метасоматического процесса пропилит-березитового профиля:

- типовая метасоматическая зональность околорудного, рудовмещающего ореола-колонки с полиминеральной маломощной тыловой березитовой зоной в обрамлении крупнообъемных пропилитовых минералого-петрохимических зон;

- типовой минеральный состав метасоматита-березита тыловой зоны - кварц, серицит, $\mathrm{Mg}-\mathrm{Fe}$ карбонаты, пирит (сульфиды) с примесью рутила, лейкоксена, апатита;

\section{СПИСОК ЛИТЕРАТУРЫ}

1. Кучеренко И.В. Проблемы рудной геологии и человеческий фактор. Часть 1. Минералого-петрохимическая зональность околожильных метасоматических ореолов в мезотермальных месторождениях золота: теория, эксперимент, природа // Известия Томского политехнического университета. Инжиниринг георесурсов. - 2017. - Т. 328. - № 7. - С. 105-118.

2. Кучеренко И.В. Проблемы рудной геологии и человеческий фактор. Часть 2. Магматизм и мезотермальное рудообразование // Известия Томского политехнического университета. Инжиниринг георесурсов. - 2018. - Т. 329. - №6. C. $148-170$

3. Буряк В.А., Летников Ф.А. 0 роли процессов регионального метаморфизма и ультраметаморфизма в развитии золотого
- замена в ходе метасоматического процесса сильным основанием калием более слабого основания натрия, частичное удаление из тыловых зон метасоматического ореола кремнезема с фиксацией его в объеме ореола в трещинах и образованием кварцевых жил и прожилков;

- поступление в образующийся метасоматический ореол из внедрившихся извне металлоносных растворов калия, серы, углекислоты, в ближнем обрамлении глубинных разломов, в данном случае рудоконтролирующего и, очевидно, раствороподводящего Кадали-Сухоложского, фемофильных магния, железа, титана, фосфора и фиксация их преимущественно в тыловых зонах ореола соответственно в составе карбонатов, рутила, лейкоксена, апатита.

оруденения // Вопросы геологии месторождений золота. Томск: Изд-во Томского университета, 1970. - С. 19-24.

4. Буряк В.А. Генетическая модель метаморфогенно-гидротермального рудообразования // Генетические модели эндогенных рудных формаций. Т. 2. - Новосибирск: Наука, 1983. C. $139-145$.

5. Brand N.W., Bottrell S.H., Miller M.F. Concentration of reduced sulphur in inclusions fluids associated with black shales hosted quartz veins gold deposits: implications for mechanisms of transport and deposition of gold and a possible exploration tool // Applied Geochemistry. - 1989. - V. 4. - Iss. 5. - P. 483-491.

6. Nelson C.E. Comparative geochemistry of jasperoids from Carlintype gold deposits of the western United States // Journal of Geochemical Exploration. - 1990. - V. 36. - Iss. 1-3. - P. 171-195. 
7. Shepherd T.J., Bottrell S.H., Miller M.F. Fluid inclusion volatiles as an exploration guide to black shale-hosted gold deposits, Dolgellau gold belt, North Wales, UK // Journal of Geochemical Exploration. - 1991. - V. 42. - Iss. 1. - P. 5-24.

8. Основные факторы онтогенеза месторождений благородных металлов сухоложского типа / В.К. Немеров, А.М. Спиридонов, Э.Р. Развозжаева, Н.Л. Матель, А.Е. Будяк, А.М. Станевич // Отечественная геология. - 2005. - № 3. - С. 17-24.

9. Evidence of local sourcing of sulphur and gold in an Archaean sediment-hosted gold deposit / V. Selvaraja, M.L. Fiorentini, H. Jeon, D.D. Savard, C.K. Laflamme, P. Guagliardo, S. Caruso, ThiHao Bui // Ore Geology Reviews. - 2017. - V. 89. - P. 909-930.

10. Этапы формирования крупномасштабной благороднометальной минерализации месторождения Сухой Лог (Восточная Сибирь): результаты изотопно-геохронологического изучения / Н.П. Лаверов, И.В. Чернышов, А.В. Чугаев, Э.Д. Баирова, Ю.В. Гольцман, В.В. Дистлер, М.А. Юдовская // Доклады PAH. - 2007. - T. 415. - № 2. - C. 236-241.

11. Этапы формирования Бодайбинского золоторудного района / И.К. Рундквист, В.А. Бобров, Т.Н. Смирнова, М.Ю. Смирнов, М.Ю. Данилова, А.А. Ащеулов // Геология рудных месторождений. - 1992. - Т. 34. - № 6. - С. 3-15.

12. Геодинамические условия формирования золоторудных месторождений Бодайбинского неопротерозойского прогиба / М.И. Кузьмин, В.В. Ярмолюк, А.М. Спиридонов, В.К. Немеров, Г.Л. Митрофанов // Доклады РАН. - 2006. - Т. 407. № 6. - C. 793-797.

13. Иванов А.И. Роль метаморфических условий преобразований углеродистых карбонатно-терригенных отложений для формирования золотого оруденения на разных этапах коллизионной эпохи развития Байкало-Патомской металлогенической провинции // Отечественная геология. - 2017. - № 4. C. $3-23$.

14. Кряжев С.Г. Генетические модели и критерии прогноза золоторудных месторождений в углеродисто-терригенных комплексах: автореф. дис. ... д-ра геол.-минерал. наук. - М., 2017. $52 \mathrm{c.}$

15. Кряжев С.Г. Изотопно-геохимические и генетические модели золоторудных месторождений в углеродисто-терригенных толщах // Отечественная геология. - 2017. - № 1. - С. 28-38.

16. Золотоносные литолого-стратиграфические уровни и условия локализации прожилково-вкрапленных руд в Хакчанском и Верхне-Хатыннах-Олботском рудных узлах (Магаданская область) / Ч.Х. Арифулов, С.Г. Кряжев, И.В. Арсентьева, М.А. Имамендинова, Н.В. Цымбалюк // Отечественная геология. - 2017. - № 4. - С. 24-43.

17. Дамдинов Б.Б. Типы благороднометального оруденения юговосточной части Восточного Саяна: состав, условия формирования, генезис: автореф. дис. ... д-ра геол.-минерал. наук. Улан-Удэ, 2018. - 52 с.

18. Сизых А.И., Юденко М.А. Метаморфизм и метаморфогенное рудообразование Тыйско-Олокитского метаморфического пояса Северного Прибайкалья // Геология и полезные ископаемые Восточной Сибири / под ред. А.И. Сизых. - Иркутск: Изд-во Иркутского гос. ун-та, 2013. - С. 68-78.

19. Паленова Е.Е. Минералогия месторождений золота Копыловское, Кавказ, Красное (Артемовский рудный узел, Бодайбинский район): автореф. дис. ... канд. геол.-минерал. наук. - М., 2015. -22 c.

20. Яловик Г.А. Геолого-структурные и вещественные особенности золоторудных месторождений в шарьяжно-надвиговых структурах Яно-Колымского и Монголо-Охотского орогенных поясов (на примере Бадранского, Карийского и Пильненского месторождений): автореф. дис. ... канд. геол.-минерал. наук. Tомск, 2016. -22 c.

21. Gold mineralization in Proterozoic black shales: Example from the Haoyaoerhudong gold deposit, Northern margin of the North Chi- na Craton / Wang Jianping, Liu Jiajun, Peng Runmin, Liu Zhenjiang, Zhao Baisheng, Li Zan, Wang Yufeng, Liu Chonghao // Ore Geology Reviews. - 2014. - V. 63. - P. 150-159.

22. Межубовский В.В. Геология и золотоносность Герфед-Николаевской рудной зоны (Енисейский кряж): автореф. дис. ... канд. геол.-минерал. наук. - Красноярск, 2017. - 24 с.

23. Буряк В.А. Метаморфизм и рудообразование. - М.: Недра, 1982. -256 c.

24. Злобин В.А. Геохимические особенности рудовмещающих черносланцевых толщ Енисейского кряжа // Микроэлементный состав осадочных толщ как показатель условий их формирования. - Новосибирск: ИГиГ СО АН СССР, 1989. - С. 105-142.

25. Синцов А.В., Лобанов М.П., Сизых В.И. Рудоносные углистые сланцы Ленского золотоносного района // Литология и полезные ископаемые. - 2003. - № 1. - С. 27-37.

26. Марченко Л.Г., Ярцева Л.А., Xueqiu Wang. Черносланцевые толщи как источник золота и платины // Геология и охрана недр. - 2005.- № 2. - С. 40-44.

27. Relationships between gold-quartz veins and disseminated PGMbearing gold-sulfide mineralization in black-shales / V.A. Buryak, V.I. Goncharov, N.A. Goryachev, N.V. Tsymbalyuk, E.G. Abissalov // Doklady Earth Sciences. - 2005. - V. 400. - Iss. 1. - P. 1-4.

28. Multiple mineralization events in the Zhaxikand Sb-Pb-Zn-Ag deposit and their relationship with the geodynamic evolution in the North Himalayan Metallogenic Belt, South Tibet / D. Wang, Y. Sheng, R. Mathur, J. Jiang, S. Shang, J. Sheng, M. Yu // Ore geology Reviews. - 2019. - V. 105. - P. 201-215.

29. Арифулов Ч.Х. Золотоносность черносланцевых толщ и обстановки формирования рудных тел / / Руды и металлы. - 2010. № 1. - C. 10-21.

30. Khanchuk A.I., Plyusnina L.P., Nikitenko E.M. The Noble Metal Distribution in the black shales of the Degdekan Gold deposit in Northeast Russia // Russian journal of Pacific Geology. 2011. - V. 5. - № 2. - P. 89-96.

31. Буряк В.А., Гончаров В.И., Горячев Н.А. Эволюционный ряд крупнообъемных золото-платиноидных месторождений в углеродистых толщах // Доклады РАН. - 2002. - Т. 387. № 4. - C. 512-515.

32. Vasilyeva I.E., Shabanova E.V., Razvozzaeva E.A. Noble metals in the insoluble carbonaceous substance of black shales and ores: Direct atomic emission data // Geochemistry International. 2012. - V. 50. - № 9. - P. 771-776.

33. Abramov B.N. The formation of black shale gold deposits in the southern environs of the Siberian Platform (Kodaro-Udokanskaya and Tallai-Karalonskaya zones) // Doklady Earth Sciences. 2013. - V. 449. - № 2. - P. 371-374.

34. Pyrite and pyrrhotite textures and composition in sediments, laminated quartz veins, and reefs at Bendigo gold mine, Australia: Insights for ore genesis / H.V. Thomas, R.R. Large, S.W. Bull, V. Maslennikov, R.F. Berry, R. Fraser, S. Fround, R. Moye // Economic Geology. - 2011. - V. 106. - Iss. 1. - P. 1-31.

35. Relationship between metamorphism and ore formation at the Sukhoi Log gold deposit hosted in black slates from the data of U$\mathrm{Th}-\mathrm{Pb}$ isotopic SHRIMP-dating of accessory minerals / M.A. Yudovskaya, V.V. Distler, N.V. Rodionov, A.V. Mokhov, A.V. Antonov, S.A. Sergeev // Geology of ore deposits. -2011 . V. 53. - Iss. 1. - P. 27-57.

36. Xu L., Lehmann B., Mao J. Seawater contribution to polymetallic Ni-Mo-PGE-Au mineralization in Early Cembrian black shales of South China: evidence from Mo isotope, PGE, TRACE element and REE Geochemistry // Ore Geology Reviews. - 2013. V. 52 . - P. $66-84$

37. The importance of black shales in the origin of the Amantaytau orogenic gold deposit in Uzbekistan: evidence from pyrite chemistry and sulphur isotope data / J. Pasava, A. Vymazalova, P. Dobes et al. // Mineral Deposita research for a High Tech World. 2013. - V. 1-4. - P. 1174-1177. 
38. P-T-X conditions on the genesis of orogenic $\mathrm{Au}(\mathrm{As}, \mathrm{Bi}, \mathrm{Ag}$ ) deposit in metasedimentary rocks of the Buracao Area, Arai Group, Brasilia Fold Belt, Brasil / G.L.C. Pires, C. Renac, E.M. Bongiolo, R. Neumann, A. Barats // Ore Geology Reviews. - 2019. V. 105 - P. $163-182$.

39. Gold mineralization and orogenic metamorphism in the Lena province of Siberia as assessed from Chertovo Koryto and Sukhoi Log deposits / M.A. Yudovskaya, V.V. Distler, V. Yu. Prokofiev, N.N. Akinfiev // Geoscience Frontiers. - 2015. - № 7. P. 453-481. - DOI: 10.1016/j.gsf.2015.07.010.

40. Synsedimentary to early diagenetic gold in black shale-hosted pyrite nodules at the Golden Mile deposit, Kalgoorlie, Western Australia / J.A. Steadman, R.R. Large, S. Meffre, P.H. Olin, L.V. Danyushevsky, D.D. Gregory, I. Belousov, E. Lounejeva, T.R. Ireland, P. Holden // Economic Geology. - 2015. - V. 110. № 5. - P. 1157-1191.

41. Groves D.I., Santosh M. The giant Jiaodong gold province: the Key to a unified model for orogenic gold deposits? // Geoscience Frontiers. - 2016. - № 7. - P. 409-417.

42. Volkov A.V., Murashov K.Y., Sidorov A.A. Geochemical peculiarities of ores from the largest Natalka gold deposit in North-Eastern Russia // Doklady Earth Sciences. - 2016. - V. 466. - № 2. P. 161-164.

43. К методике оценки прогнозных ресурсов рудного золота в углеродистых карбонатно-терригенных отложениях Бодайбинского рудного района / В.Д. Конкин, А.И. Иванов, Е.Е. Котельников, В.Е. Васюков, И.О. Захаров // Отечественная геология. 2017. - № 4. - C. 64-80.

44. Ta Nang gold deposit in the black shales of Central Vietnam / T.T. Anh, T.T. Hoa, P.T. Dung, V.H. Li, N.T. Mai, I.V. Gaskov, A.S. Borisenko, A.E. Izokh // Russian Geology and Geophysics. 2015. - V. 56. - Iss. 10. - P. 1414-1427.

45. Noble metals in black shales of the Sukhoi Log gold deposit (East Siberia): evidence from scintillation arc atomic-emission spectrometry / I.E. Vasil'eva, E.V. Shabanova, E.M. Goryacheva, 0.T. Sotskaya, V.A. Labusov, A.A. Dzyuba, 0.A. Nekludov // Russian Geology and Geophysics. - 2018. - V. 59. - № 8. - P. 997-1009.

46. The gold ore deposit Bakyrchic and views on the formation of the mineral deposits in black shale strata / Z. Umarbekova, R. Seltmann, K. Dyussembaeva, M. Kokkuzova // Proceedings of the $17^{\text {th }}$ International Multidisciplinary Scientific GeoConference SGEM. - 2017. - V. 17. - Iss. 11. - P. 1111-1118. DOI 10.5593/sgem2017/11/S04.142. URL: www.sgem.org (дата обращения 20.04.2019).

47. Steadmen J.A., Large R.R. Synsedimentary, diagenetic and metamorphic pyrite, pyrrhotite and marcasite at the Homestake BIF-hosted gold deposit, South Dakota, USA: Insights on Au-As ore genesis from textural and La-ICP-MS trace element studies // Economic Geology. - 2016. - V. 111. - Iss. 7. - P. 1731-1752.

48. A black shale protolith for gold-tellurium mineralization in the Dalradian Supergroup (Neoproterozoic) of Britain and Ireland / J. Parnell, M. Perez, J. Armstrong, L. Bullock, J. Feldmann, A.J. Boyce // Applied Earth Science. - 2017. - V. 126. - № 4. P. 161-175. URL: https://doi.org/10.1080/03717453.2017. 1404682 (дата обращения 20.04.2019).

49. Tatarinov A.V., Yalovic L.I., Vanin V.A. Spherical microparticles from gold-bearing quartz veins of the Irokinda deposit, Western Transbaikalia // Geodynamics and Tectonophysics Open Access. - 2016. - V. 7. - Iss. 4. - P. 651-662.

50. Augustin J., Gaboury D. Multi-stage and multi-sourced fluid and gold in the formation of orogenic gold deposits in the world-class Mana district of Burcina Faso-Revealed by LA-ICP-MS analysis of pyrites and arsenopyrites // Ore Geology Reviews. - 2019. V. $104 .-$ P. $495-521$.

51. Damdinov B.B., Damdinova L.B. Zun-0spa gold deposit, Eastern Sayan: Geology, ore composition and genesis // Geology of ore deposits. - 2018. - V. 60. - Iss. 3. - P. 241-264.
52. Nature and source of the ore-forming fluids associated with orogenic gold deposits in the Dharwar craton / B. Mishra, K.L. Pruseth, P. Nazarika, S.S. Chinnasamy // Geoscience Frontiers. 2018. - V. 9. - Iss. 3. - P. 715-726.

53. Formation of epizonal gold mineralization within the Latimojong metamorphic complex, Sulawesi, Indonesia: Evidence from mineralogy, fluid inclusions and Raman spectroscopy / A.Y.A. Hakim, F. Melcher, W. Prochaska, R. Bakker, G. Rantitsch // Ore Geology reviews. - 2018. - V. 97. - P. 88-108.

54. Kondrat'eva L.A., Anisimova G.S., Zaitsev A.I. The Zaderzhninskoe gold deposit: mineral composition, fluid inclusions and age (South Verkhoyansk region) // Russian Geology and Geophysics. 2018. - V. 59. - Iss. 10. - P. 1288-1300.

55. Gamyanin G.N., Fridovsky V.Y., Vikent'eva O.V. Noble metal mineralization of the Adycha-Taryn metallogenic zone: Geochemistry of stable isotopes, fluid regime and ore formation conditions // Russian Geology and Geophysics. - 2018. - V. 59. Iss. 10. - P. 1271-1287.

56. Local and regional mass transfer during trusting, veining and boudinage in the genesis of the giant shale-hosted Paracatu gold deposit, Minas Gerais, Brazil / N.H.S. Oliver, B. Thomson, F.H. Freitas-Silva, R.J. Holcombe, B. Rusk, B.S. Almeida, K. Faure, G.R. Davidson, E.L. Esper, P.J. Guimaraes, M.A. Dardenne // Economic Geology. - 2015. - V. 110. - Iss. 7. - P. 1803-1834.

57. Chemical evolution of pyrite at the Kopylovsky and Kavkaz black shale-hosted gold deposits, Bodaybo district, Russia: Evidence from EPMA and La-ICP-MS data / E.E. Palenova, E.V. Belogub, 0.Y. Plotinskaya, K.A. Novoselov, V.V. Maslennikov, V.A. Kotlyarov, I.A. Blinov, A.A. Kuzmenko, I.G. Griboedova // Geology of ore deposits. - 2015. - V. 57. - Iss. 1. - P. 64-84.

58. Gold concentrations in metamorphic fluids: a LA-ICP-MS study of fluid inclusions from the Alpine orogenic belt / K. Rauchenstein-Martinek, T. Wagner, M. Walle, C.A. Heinrich // Chemical Geology. - 2014. - V. 385. - P. 70-83.

59. Age, origin and significance of nodular sulfides in $2680 \mathrm{Ma}$ carbonaceous black shale of the Eastern Goldfields Superterrane, Yilgarn Craton, Western Australia / J.A. Steadman, R.R. Large, S. Meffre, S.W. Bull // Precambrian Research. - 2013. V. 230 . - P. 227-247.

60. Large R.R., Maslennikov V.V. A carbonaceous sedimentary source-rock model for carlin-type and orogenic gold deposits / Economic Geology. - 2011. - V. 106. - Iss. 3. P. 331-358.

61. Жариков В.А. Некоторые закономерности метасоматических процессов / / Метасоматические изменения боковых пород и их роль в рудообразовании. - М.: Недра, 1966. - С. 47-63.

62. Плющев Е.В. Гидротермально-метасоматическое минералообразование как региональное геологическое явление и его металлогеническое значение // Геохимические методы при поисках скрытого оруденения. - М.: Наука, 1984. - С. 11-20.

63. Шер С.Д. Околорудные изменения, сопутствующие золотокварцевым жилам в Ленском золотоносном районе // Метасоматические изменения боковых пород и их роль в рудообразовании. - М.: Недра, 1966. - С. 282-291.

64. Коновалов И.В. Околорудная зональность одного золоторудного месторождения (Ленский район) // Геология и геофизика. 1973. - № 1. - C. 123-125.

65. Шмотов А.П. Тектонические деформации и сопряженные с ними гидротермально-метасоматические преобразования вмещающих пород (Ленский золотоносный район) // Доклады АН CCCP. - 1974. - T. 218. - № 1. - C. 178-181.

66. Шаров В.Н., Шмотов А.П., Коновалов И.В. Метасоматическая зональность и связь с ней оруденения. - Новосибирск: Наука, 1978. - 103 c.

67. Русинов В.Л., Русинова О.В., Кряжев С.Г. Околорудный метасоматизм терригенных углеродистых пород в Ленском золоторудном районе // Геология рудных месторождений. - 2008. T. 50. - № 1. - C. 3-46. 
68. Намолов Е.А., Чиркова В.М. Типоморфные ассоциации и региональная минеральная зональность золото-кварцевых жил Бодайбинского рудного района // Геология и полезные ископаемые Восточной Сибири: Тезисы докладов регион. научной конф. - Иркутск: Иркутский гос. ун-т, 1986. - С. 62-63.

69. Петролого-геохимические черты околорудного метасоматизма в золоторудном месторождении Сухой Лог (Ленский район).

Ч. 2. Петрология околорудного метасоматизма / И.В. Куче- ренко, Р.Ю. Гаврилов, В.Г. Мартыненко, А.В. Верхозин // Известия Томского политехнического университета. - 2012. T. 320. - № 1. - C. 28-37.

70. Гаврилов А.М., Кряжев С.Г. Минералого-геохимические особенности руд месторождения Сухой Лог // Разведка и охрана недр. - 2008. - № 8. - С. 3-16.

Поступила 24.04.2019 2.

\section{Информация об авторах}

Кучеренко И.В., доктор геолого-минералогических наук, профессор, Национальный исследовательский Томский политехнический университет. 
UDC 553.3/.4.06:551.25:553.2:167-047.58

\title{
ORE GEOLOGY PROBLEMS AND THE HUMAN FACTOR. PART 3. METAMORPHISM AND MESOTHERMAL OREFORMATION
}

\author{
Igor V. Kucherenko, \\ kivr@tpu.ru \\ National Research Tomsk Polytechnic University, \\ 30, Lenin Avenue, Tomsk, 634050, Russia.
}

The relevance of the research. The conditions of the known large mesothermal gold deposits formation into black shales states of different age form the subject of animated discussion which often acquires the signs of substitute and probably therefore the endless one as a result of exception by concrete author or author's group of the facts important for the problem solution but which do not fit in database of developing by him/them ideas, from the consideration, discussion, generalization.

The main aim of the research. To obtain the correct results required for deepening the hydrothermal ore formation theory and developing, improving the effective forecast-search criteria of the deposits it is necessary to remove this negative manifestation of the human factor and return the discussion in normal course by means of including in scientific expression the "handy» and "non handy» facts in reconstruction of ore formation.

The methods of the research. The author has analyzed the database proposed long ago and recently for substantiation of the metamorphic-hydrothermal and others hypotheses of mesothermal gold deposits formation into black shales strates. The paper introduces the author's materials, including the analytic data - the results of the full chemical silicate analysis (wet) of rocks, atomic-absorption analysis of the content of gold, silver, mercury into rocks, petrochemic balance calculations of the between-zoning migration of chemical elements into near-ore metasomatic haloes, mathematical computing of the analyses results (content oregenous elements).

The results of the research. The author made the conclusion on geology-genetic uniformity of mesothermal gold deposits formed into crystalline substratum and black shales. The following facts: 1) control of gold deposits by deep faults; 2) similar geologic age of early plutons, massifs of palingenetic granitoids with large accompanying dikes of average-soured rocks and late dikes of the moderatelyalkaline dolerites, dolerites, leucodolerites of tillore, insideore, afterore generations, including transformed into hightemperature biotiteamphibole hornblende metasomatites of insideore dikes-fluidconductors, and ores; 3) authentic mineral-petrochemic zoning of the near-ore metasomatic haloes in both substratum, formed in conditions of potassium-sulphurously-carbon-dioxidic metasomatism of propilite-beresitic type with entrance into haloes of potassium, restoring sulphur, carbon dioxide, removal of sodium and partly silicium; 4) inheritance by the nearore metasomatites of the petrochemic type insidedoleritic metasomatism and contrasting anomalies of the femic ( $\mathrm{Mg}, \mathrm{Fe}, \mathrm{P}, \mathrm{Ti}$ ) elements; 5) isotopic relations of sulphides sulphur and carbonates carbon of ores and nearore metasomatites meeting the meteoritic standard (the mantle), prove the conclusion. The enumerated facts eliminate the participation of metamorphism in ore formation.

In Lensk region, as well as in others goldore regions of mountain-folded Siberian craton frame, mesothermal gold deposits are formed into antidromic granite-diorite-dolerite fluid-ore-magmatic complexes composition at late basic stage of their function, and insideore dikes-fluid conductors of moderately-alkaline dolerites are the link between basic hearthes of mantle - the sources of gold-bearing solutions, and deposits in the crust.

Paper structure. The $3^{\text {rd }}$ part of the paper has the following sections: subject of the problems and the formulation of the task; mineralpetrochemic zoning of the nearore propilitic-beresitic type metasomatic haloes in mesothermal gold deposits formed into crystalline substratum and black shales series; mineral-petrochemic zoning of the gold deposit Sukhoi Log nearore metasomatic haloe. In the $4^{\text {th }}$ part of the paper there are the following sections: the distribution of oregenous elements into nearore expanse of the mesothermal gold deposits formed into crystalline substratum and black shales series; the discussion of the results, conclusion and references.

\section{Key words:}

Mesothermal gold deposits, crystalline substratum, black shales, magmatism, metamorphism, ore formation, human factor.

\section{REFERENCES}

1. Kucherenko I.V. Ore geology problems and the human factor. Part 1. Mineral-petrochemic zoning of the near-veins metasomatic aureoles in the mesothermal gold deposits: theory, experiment, nature. Bulletin of the Tomsk Polytechnic University. Geo Assets Engineering, 2017, vol. 328, no. 7, pp. 105-118. In Rus.

2. Kucherenko I.V. Ore geology problems and the human factor. Part 2. Magmatism and mesothermal ore-formation. Bulletin of the Tomsk Polytechnic University. Geo Assets Engineering, 2018, vol. 329, no. 6, pp. 148-170. In Rus.

3. Buryak V.A., Letnikov F.A. 0 roli protsessov regionalnogo metamorfizma i ultrametamorfizma v razvitii zolotogo orudeneniya [Role of regional metamorphism and ultrametamorphism in development of gold ore formation]. Voprosy geologii mestorozhdeniy zolota [The problems of the gold deposits geology]. Tomsk, Tomsk Polytechnic Institute Publ., 1970, pp. 19-24.

4. Buryak V.A. Geneticheskaya model metamorfogenno-gidrotermalnogo rudoobrazovaniya [The genetic model of metamorphogenetic hydrothermal ore-formation]. Geneticheskie modeli endo- gennykh rudnykh formatsy [The genetic models of the endogenous ore formations]. Novosibirsk, Nauka Publ., 1983, vol. 2, pp. $139-145$.

5. Brand N.W., Bottrell S.H., Miller M.F. Concentration of reduced sulphur in inclusions fluids associated with black shales hosted quartz veins gold deposits: implications for mechanisms of transport and deposition of gold and a possible exploration tool. Applied Geochemistry, 1989, vol. 4, Iss. 5, pp. 483-491.

6. Nelson C.E. Comparative geochemistry of jasperoids from Carlintype gold deposits of the western United States. Journal of Geochemical Exploration, 1990, vol. 36, Iss. 1-3, pp. 171-195.

7. Shepherd T.J., Bottrell S.H., Miller M.F. Fluid inclusion volatiles as an exploration guide to black shale-hosted gold deposits, Dolgellau gold belt, North Wales, UK. Journal of Geochemical Exploration, 1991, vol. 42, Iss. 1, pp. 5-24.

8. Nemerov V.K., Spiridonov A.M., Razvozzhaeva E.R., Matel N.L., Budyak A.E., Stanevich A.M. The ontogenesis main factors of the noble metals deposits of the Sukhoi log type. Domestic geology, 2005, no. 3, pp. 17-24. In Rus. 
9. Selvaraja V., Fiorentini M.L., Jeon H., Savard D.D., Laflamme C.K., Guagliardo P., Caruso S., Bui Thi-Hao. Evidence of local sourcing of sulphur and gold in an Archaean sediment-hosted gold deposit. Ore Geology Reviews, 2017, vol. 89, pp. 909-930.

10. Laverov N.P., Chernyshov I.V., Chugaev A.V., Bairova E.D., Goltsman Yu.V., Distler V.V., Yudovskaya M.A. Etapy formirovaniya krupnomasshtabnoy blagorodnometalnoy mineralizatsii mestorozhdeniya Sukhoy Log (Vostochnaya Sibir): rezultaty izotopno-geokhronologicheskogo izucheniya [The stages of formation of the large-scale noble-metal mineralization into Sukhoi Log deposit (Eastern Siberia): isotope-geochronological study results]. Papers of RAC, 2007, vol. 415, no. 2, pp. 236-241.

11. Rundkvist I.K., Bobrov V.A., Smirnova T.N., Smirnov M.Yu., Danilova M.Yu., Ashheulov A.A. Etapy formirovaniya Bodaybinskogo zolotorudnogo rayona [The stages of Bodaibo gold-ore region formation]. Geologiya rudnykh mestorozhdeniy, 1992, vol. 34 , no. 6, pp. 3-15.

12. Kuzmin M.I., Yarmolyuk V.V., Spiridonov A.M., Nemerov V.K., Mitrofanov G.L. Geodinamicheskie usloviya formirovaniya zolotorudnykh mestorozhdeniy Bodaybinskogo neoproterozoyskogo progiba [Geodynamic conditions of formation of Bodaibo Proterozoik trough gold-ore deposits]. Papers of RAC, 2006, vol. 407, no. 6, pp. 793-797.

13. Ivanov A.I. The part of metamorphic conditions of the carbonaceous carbon-bearing-terrigenous sediments for gold mineralization formation during different stages of the Baikal-Patom metallogenic province. Domestic geology, 2017, no. 4, pp. 3-23. In Rus.

14. Kryazhev S.G. Geneticheskie modeli i kriterii prognoza zolotorud nykh mestorozhdeniy $v$ uglerodisto-terrigennykh kompleksakh. Avtoreferat Dis. Dokt. nauk [The genetic models and forecast criteria of the gold-ore deposits into carbonaceous-terrigenous complexes. Dr. Diss. Abstract]. Moscow, 2017. 52 p.

15. Kryazhev S.G. Isotopic-geochemic and genetic models of the goldore deposits into the carbon-bearing-terrigenous series. Domestic geology, 2017, no. 1, pp. 28-38. In Rus.

16. Arifulov Ch.Kh., Kryazhev S.G., Arsenteva I.V., Imamendinova M.A., Tszymbalyuk N.V. Auriferous lithologic-stratigraphic levels and conditions of the streaky-impregnated ores localization in Khanchanskii and Upper Khatynnan-Olbotskii ore nodes (Magadanskii region). Domestic geology, 2017, no. 4, pp. 24-43. In Rus.

17. Damdinov B.B. Tipy blagorodnometalnogo orudeneniya yugo-vostochnoy chasti Vostochnogo Sayana: sostav, usloviya formirovaniya, genesis. Avtoreferat Dis. Dokt. nauk [The types of the noblemetal mineralization of South-Eastern part of East Eastern Sayan: composition, conditions of formation, genesis. Dr. Diss. Abstract]. Ulan-Ude, 2018. $52 \mathrm{p}$.

18. Sizykh A.I., Yudenko M.A. Metamorfizm i metamorfogennoe rudoobrazovanie Tyysko-Olokitskogo metamorficheskogo poyasa Severnogo Pribaykalya [Metamorphism and metamorphogenous ore-formation of the Northern Transbaikalia Tyisko-Olokitskil metamorphic belt]. Geologiya i poleznye iskopaemye Vostochnoy Sibiri [Geology and minerals of Eastern Siberia]. Ed. by A.I. Sizykh. Irkutsk, Irkutsk State University Press, 2013. pp. 68-78.

19. Palenova E.E. Mineralogiya mestorozhdeniy zolota Kopylovskoe, Kavkaz, Krasnoe (Artemovskiy rudny uzel, Bodaybinskiy rayon). Avtoreferat Dis. Kand. nauk [Mineralogy of the gold deposits Kopylovskoe, Kavkaz, Krasnoe (Artemovskiy ore node, Bodaybinskiy region). Cand. Diss. Abstract]. Moscow, 2015. 22 p.

20. Yalovik G.A. Geologo-strukturnye i veshchestvennye osobennosti zolotorudnykh mestorozhdeniy $v$ sharyazhno-nadvigovykh strukturakh Yano-Kolymskogo i Mongolo-Okhotskogo orogennykh poyasov (na primere Badranskogo, Kariyskogo i Pilnenskogo mestorozhdeniy). Avtoreferat Dis. Kand. nauk [Geologic, structural and material peculiarities of the gold-ore deposits in the overthrust sheet-overlap textures of Yano-Kolymskii and Mongolo-
Ohotskii orogenic nodes (for example Badranskoe, Kariiskoe and Pilnenskoe deposits). Cand. Diss. Abstract]. Tomsk, 2016. 22 p.

21. Jianping Wang, Jiajun Liu, Runmin Peng, Zhenjiang Liu, Baisheng Zhao, Zan Li, Yufeng Wang, Liu Chonghao. Gold mineralization in Proterozoic black shales: Example from the Haoyaoerhudong gold deposit, Northern margin of the North China Craton. Ore Geology Reviews, 2014, vol. 63, pp. 150-159.

22. Mezhubovskiy V.V. Geologiya i zolotonosnost Gerfed-Nikolaevskoy rudnoy zony (Eniseyskiy kryazh). Avtorefertat Dis. Kand. nauk [Geology and the gold-bearing of the Gerfed-Nikolaevskaya ore zone (Eniseiskiy ridge). Cand. Diss. Abstract]. Krasnoyarsk, 2017. $24 \mathrm{p}$.

23. Buryak V.A. Metamorfizm i rudoobrazovanie [Metamorphism and ore-formation]. Moscow, Nedra Publ., 1982. 256 p.

24. Zlobin V.A. Geokhimicheskie osobennosti rudovmeshchayushchikh chernoslantsevykh tolshch Eniseyskogo kryazha [Geochemic peculiarities of the ore-bearing black shales terranes of Eniseiskiy ridge]. Mikroelementny sostav osadochnykh tolshch kak pokazatel usloviy ikh formirovaniya [Microelement composition of the sedimentary terranes as indicator of conditions their formation]. N0vosibirsk, IGiG S0 AN SSSR Publ., 1989. pp. 105-142.

25. Sintsov A.V., Lobanov M.P., Sizykh V.I. Metalliferous carbonaceous shales of Lenskii auriferous region. Litologiya i poleznye iskopaemye, 2003, no. 1, pp. 27-37. In Rus.

26. Marchenko L.G., Yartseva L.A., Xueqiu Wang. Black shale terranes as the source of gold and platinum. Geologiya $i$ okhrana nedr, 2005, no. 2, pp. 40-44. In Rus.

27. Buryak V.A., Goncharov V.I., Goryachev N.A., Tsymbalyuk N.V., Abissalov E.G. Relationships between gold-quartz veins and disseminated PGM-bearing gold-sulfide mineralization in black-shales. Doklady Earth Sciences, 2005, vol. 400, Iss. 1, pp. 1-4.

28. Wang D., Sheng Y., Mathur R., Jiang J., Shang S., Sheng J., Yu M. Multiple mineralization events in the Zhaxikand $\mathrm{Sb}-\mathrm{Pb}-\mathrm{Zn}-\mathrm{Ag}$ deposit and their relationship with the geodynamic evolution in the North Himalayan Metallogenic Belt, South Tibet. Ore geology Reviews, 2019, vol. 105, pp. 201-215.

29. Arifulov Ch.Kh. Gold-bearing of the black shales terranes and formation situations of ore bodies. Rudy i metally, 2010, no. 1, pp. 10-21. In Rus.

30. Khanchuk A.I., Plyusnina L.P., Nikitenko E.M. The Noble Metal Distribution in the black shales of the Degdekan Gold deposit in Northeast Russia. Russian journal of Pacific Geology, 2011, vol. 5, no. 2, pp. 89-96.

31. Buryak V.A., Goncharov V.I., Goryachev N.A. Evolyutsionny ryad krupnoobemnykh zoloto-platinoidnykh mestorozhdeniy $\mathrm{v}$ uglerodistykh tolshchakh [Evolutionary raw of the gold-platinoid deposits into carbonaceous terranes]. Papers of RAC, 2002, vol. 387, no. 4 , pp. 512-515.

32. Vasilyeva I.E., Shabanova E.V., Razvozzaeva E.A. Noble metals in the insoluble carbonaceous substance of black shales and ores: Direct atomic emission data. Geochemistry International, 2012, vol. 50, no. 9, pp. 771-776.

33. Abramov B.N. The formation of black shale gold deposits in the southern environs of the Siberian Platform (Kodaro-Udokanskaya and Tallai-Karalonskaya zones). Doklady Earth Sciences, 2013, vol. 449, no. 2, pp. 371-374.

34. Thomas H.V., Large R.R., Bull S.W., Maslennikov V., Berry R.F., Fraser R., Fround S., Moye R. Pyrite and pyrrhotite textures and composition in sediments, laminated quartz veins, and reefs at Bendigo gold mine, Australia: Insights for ore genesis. Economic Geology, 2011, vol. 106, Iss. 1, pp. 1-31.

35. Yudovskaya M.A., Distler V.V., Rodionov N.V., Mokhov A.V., Antonov A.V., Sergeev S.A. Relationship between metamorphism and ore formation at the Sukhoi Log gold deposit hosted in black slates from the data of U-Th-Pb isotopic SHRIMP-dating of accessory minerals. Geology of ore deposits, 2011, vol. 53, Iss. 1, pp. $27-57$. 
36. Xu L., Lehmann B., Mao J. Seawater contribution to polymetallic Ni-Mo-PGE-Au mineralization in early Cembrian black shales of South China: evidence from Mo isotope, PGE, TRACE element and REE Geochemistry. Ore Geology Reviews, 2013, vol. 52, pp. 66-84.

37. Pasava J., Vymazalova A., Dobes P. The importance of black shales in the origin of the Amantaytau orogenic gold deposit in Uzbekistan: evidence from pyrite chemistry and sulphur isotope data. Mineral Deposita research for a High Tech World, 2013, vol. 1-4, pp. 1174-1177.

38. Pires G.L.C., Renac C., Bongiolo E.M., Neumann R., Barats A. $\mathrm{P}-\mathrm{T}-\mathrm{X}$ conditions on the genesis of orogenic $\mathrm{Au}(\mathrm{As}, \mathrm{Bi}, \mathrm{Ag})$ deposit in metasedimentary rocks of the Buracao Area, Arai Group, Brasilia Fold Belt, Brasil. Ore Geology Reviews, 2019, vol. 105, pp. 163-182.

39. Yudovskaya M.A., Distler V.V., Prokofiev V.Yu., Akinfiev N.N. Gold mineralization and orogenic metamorphism in the Lena province of Siberia as assessed from Chertovo Koryto and Sukhoi Log deposits. Geoscience Frontiers, 2015, no. 7, pp 453-481. DOI: 10.1016/j.gsf.2015.07.010.

40. Steadman J.A., Large R.R., Meffre S., Olin P.H., Danyushevsky L.V., Gregory D.D., Belousov I., Lounejeva E., Ireland T.R., Holden P. Synsedimentary to early diagenetic gold in black shalehosted pyrite nodules at the Golden Mile deposit, Kalgoorlie, Western Australia. Economic Geology, 2015, vol. 110, no. 5, pp. 1157-1191.

41. Groves D.I., Santosh M. The giant Jiaodong gold province: the Key to a unified model for orogenic gold deposits? Geoscience Frontiers, 2016, no. 7, pp. 409-417.

42. Volkov A.V., Murashov K.Y., Sidorov A.A. Geochemical peculiarities of ores from the largest Natalka gold deposit in North-Eastern Russia. Doklady Earth Sciences, 2016, vol. 466, no. 2, pp. 161-164.

43. Konkin V.D., Ivanov A.I., Kotelnikov E.E., Vasyukov V.E., Zakharov I.0. To methods of the forecast resources valuation of ore gold in carbonaceous carbon-bearing-terrigenous sediments of Bodaibo ore region. Domestic geology, 2017, no. 4, pp. 64-80. In Rus.

44. Anh T.T., Hoa T.T., Dung P.T., Li V.H., Mai N.T., Gaskov I.V., Borisenko A.S., Izokh A.E. Ta Nang gold deposit in the black shales of Central Vietnam. Russian Geology and Geophysics, 2015, vol. 56, Iss. 10, pp. 1414-1427.

45. Vasileva I.E., Shabanova E.V., Goryacheva E.M., Sotskaya 0.T., Labusov V.A., Dzyuba A.A., Nekludov 0.A. Noble metals in black shales of the Sukhoi Log gold deposit (East Siberia): evidence from scintillation arc atomic-emission spectrometry. Russian Geology and Geophysics, 2018, vol. 59, no. 8, pp. 997-1009.

46. Umarbekova Z., Seltmann R., Dyussembaeva K., Kokkuzova M. The gold ore deposit Bakyrchic and views on the formation of the mineral deposits in black shale strata. Proc. of the 17th International Multidisciplinary Scientific GeoConference SGEM, 2017, vol. 17, Iss. 11, pp. 1111-1118; DOI: 10.5593/sgem2017/11/ S04.142 Available at: www.sgem.org (accessed 20 April 2019).

47. Steadmen J.A., Large R.R. Synsedimentary, diagenetic and metamorphic pyrite, pyrrhotite and marcasite at the Homestake BIF-hosted gold deposit, South Dakota, USA: Insights on Au-As ore genesis from textural and La-ICP-MS trace element studies. Economic Geology, 2016, vol. 111, Iss. 7, pp. 1731-1752.

48. Parnell J., Perez M., Armstrong J., Bullock L., Feldmann J., Boyce A.J. A black shale protolith for gold-tellurium mineralization in the Dalradian Supergroup (Neoproterozoic) of Britain and Ireland. Applied Earth Science, 2017, vol. 126, no. 4, pp. 161-175. Available at: https://doi.org/10.1080/03717453.2017.1404682 (accessed 20 April 2019).

49. Tatarinov A.V., Yalovic L.I., Vanin V.A. Spherical microparticles from gold-bearing quartz veins of the Irokinda deposit, Western Transbaikalia. Geodynamics and Tectonophysics Open Access, 2016, vol. 7, Iss. 4, pp. 651-662.
50. Augustin J., Gaboury D. Multi-stage and multi-sourced fluid and gold in the formation of orogenic gold deposits in the world-class Mana district of Burcina Faso-Revealed by LA-ICP-MS analysis of pyrites and arsenopyrites. Ore Geology Reviews, 2019, vol. 104, pp. 495-521.

51. Damdinov B.B., Damdinova L.B. Zun-Ospa gold deposit, Eastern Sayan: Geology, ore composition and genesis. Geology of ore deposits, 2018, vol. 60, Iss. 3, pp. 241-264.

52. Mishra B., Pruseth K.L., Nazarika P., Chinnasamy S.S. Nature and source of the ore-forming fluids associated with orogenic gold deposits in the Dharwar craton. Geoscience Frontiers, 2018, vol. 9, Iss. 3, pp. 715-726.

53. Hakim A.Y.A., Melcher F., Prochaska W., Bakker R., Rantitsch G. Formation of epizonal gold mineralization within the Latimojong metamorphic complex, Sulawesi, Indonesia: Evidence from mineralogy, fluid inclusions and Raman spectroscopy. Ore Geology reviews, 2018, vol. 97, pp. 88-108.

54. Kondrateva L.A., Anisimova G.S., Zaitsev A.I. The Zaderzhninskoe gold deposit: mineral composition, fluid inclusions and age (South Verkhoyansk region). Russian Geology and Geophysics, 2018, vol. 59, Iss. 10, pp. 1288-1300.

55. Gamyanin G.N., Fridovsky V.Y., Vikenteva 0.V. Noble metal mineralization of the Adycha-Taryn metallogenic zone: Geochemistry of stable isotopes, fluid regime and ore formation conditions. Russian Geology and Geophysics, 2018, vol. 59, Iss. 10, pp. 1271-1287.

56. Oliver N.H.S., Thomson B., Freitas-Silva F.H., Holcombe R.J., Rusk B., Almeida B.S., Faure K., Davidson G.R., Esper E.L., Guimaraes P.J., Dardenne M.A. Local and regional mass transfer during trusting, veining and boudinage in the genesis of the giant shale-hosted Paracatu gold deposit, Minas Gerais, Brazil. Economic Geology, 2015, vol. 110, Iss. 7, pp. 1803-1834.

57. Palenova E.E., Belogub E.V., Plotinskaya 0.Y., Novoselov K.A., Maslennikov V.V., Kotlyarov V.A., Blinov I.A., Kuzmenko A.A., Griboedova I.G. Chemical evolution of pyrite at the Kopylovsky and Kavkaz black shale-hosted gold deposits, Bodaybo district, Russia: Evidence from EPMA and La-ICP-MS data. Geology of ore deposits, 2015, vol. 57, Iss. 1, pp. 64-84.

58. Rauchenstein-Martinek K., Wagner T., Walle M., Heinrich C.A. Gold concentrations in metamorphic fluids: a LA-ICP-MS study of fluid inclusions from the Alpine orogenic belt. Chemical Geology, 2014, vol. 385, pp. 70-83.

59. Steadman J.A., Large R.R., Meffre S., Bull S.W. Age, origin and significance of nodular sulfides in 2680 Ma carbonaceous black shale of the Eastern Goldfields Superterrane, Yilgarn Craton, Western Australia. Precambrian Research, 2013, vol. 230, pp. 227-247.

60. Large R.R., Maslennikov V.V. A carbonaceous sedimentary source-rock model for carbin-type and orogenic gold deposits. Economic Geology, 2011, vol. 106, Iss. 3, pp. 331-358.

61. Zharikov V.A. Nekotorye zakonomernosti metasomaticheskikh protsessov [Some regularities of metosomatic processes]. Metasomaticheskie izmeneniya bokovykh porod i ikh rol v rudoobrazovanii [Metasomatic alterations of the lateral rocks and their part in ore formation]. Moscow, Nedra Publ., 1966. pp. 47-63.

62. Plyushchev E.V. Gidrotermalno-metasomaticheskoe mineraloobrazovanie kak regionalnoe geologicheskoe yavlenie i ego metallogenicheskoe znachenie [Hydrothermal-metasomatic mineral formation as regional geologic phenomenon and its metallogenic meaning]. Geokhimicheskie metody pri poiskakh skrytogo orudeneniya [Geochemic methods in prospecting concealed mineralization]. Moscow, Nauka Publ., 1984. pp. 11-20.

63. Sher S.D. Okolorudnye izmeneniya, soputstvuyushchie zolotokvartsevym zhilam v Lenskom zolotonosnom rayone [Near-ore changings accompanying gold-quartz veins in Lenskii auriferous]. Metasomaticheskie izmeneniya bokovykh porod i ikh rol v rudoobrazovanii [Metasomatic alterations of the lateral rocks and their part in ore formation]. Moscow, Nedra Publ., 1966. pp. 282-291. 
64. Konovalov I.V. Near-ore zoning of one gold-ore deposit (Lenskii region). Geologiya i geofizika, 1973, no. 1, pp. 123-125. In Rus.

65. Shmotov A.P. Tektonicheskie deformatsii i sopryazhennye s nimi gidrotermalno-metasomaticheskie preobrazovaniya vmeshchayushchikh porod (Lenskiy zolotonosny rayon) [Tectonic deformations and hydrothermal metosomatic alterations of the containing rocks associated with them (Lenskii auriferous region)]. Papers of AC SSSR, 1974, vol. 218, no. 1, pp. 178-181.

66. Sharov V.N., Shmotov A.P., Konovalov I.V. Metasomaticheskaya zonalnost $i$ suyaz s ney orudeneniya [Metasomatic zoning and relation of mineralization to it]. Novosibirsk, Nauka Publ., 1978. $103 \mathrm{p}$.

67. Rusinov V.L., Rusinova 0.V., Kryazhev S.G. Near ore metasomatism of the terrigenous carbonaceous rocks in Lenskii auriferous region. Geologiya rudnykh mestorozhdeniy, 2008, vol. 50, no. 1, pp. 3-46. In Rus.

68. Namolov E.A., Chirkova V.M. Tipomorfnye assotsiatsii i regionalnaya mineralnaya zonalnost zoloto-kvartsevykh zhil Boday-

\section{Information about the authors}

binskogo rudnogo rayona [Typomorphic association and regional mineral zoning of the gold-quartz veins of Bodaybinskiy ore region]. Geologiya i poleznye iskopaemye Vostochnoy Sibiri. Tezisy dokladov regionalnoy nauchnoy konferentsii [Geology and minerals of Eastern Siberia. Papers abstracts of the regional scientific conference]. Irkutsk, 1986. pp. 62-63.

69. Kucherenko I.V., Gavrilov R.Yu., Martynenko V.G., Verkhozin A.V. Petrologic geochemic features of the near ore metasomatism in gold-ore deposit Sukhoi Log (Lenskii region). Part 2. Petrologia of near-ore metasomatism. Bulletin of the Tomsk Polytechnic University, 2012, vol. 320, no. 1, pp. 28-37. In Rus.

70. Gavrilov A.M., Kryazhev S.G. Mineral-geochemic ores peculiarities of the deposit Sukhoi Log. Razvedka i okhrana nedr, 2008, no. 8, pp. 3-16. In Rus.

Received: 24 April 2019.

Igor V. Kucherenko, Dr. Sc., professor, National Research Tomsk Polytechnic University. 